\title{
Clinical decision support systems-based interventions to improve medication outcomes: A systematic literature review on features and effects
}

\author{
Leila Shahmoradi ${ }^{1}$, Reza Safdari ${ }^{1}$, Hossein Ahmadi ${ }^{2}$, Maryam Zahmatkeshan $^{3 *}$ (D)
}

Received: 13 Apr 2019

Published: 22 Feb 2021

\section{Abstract}

Background: Clinical decision support systems (CDSSs) interventions were used to improve the life quality and safety in patients and also to improve practitioner performance, especially in the field of medication. Therefore, the aim of the paper was to summarize the available evidence on the impact, outcomes and significant factors on the implementation of CDSS in the field of medicine.

Methods: This study is a systematic literature review. PubMed, Cochrane Library, Web of Science, Scopus, EMBASE, and ProQuest were investigated by 15 February 2017. The inclusion requirements were met by 98 papers, from which 13 had described important factors in the implementation of CDSS, and 86 were medicated-related. We categorized the system in terms of its correlation with medication in which a system was implemented, and our intended results were examined. In this study, the process outcomes (such as; prescription, drug-drug interaction, drug adherence, etc.), patient outcomes, and significant factors affecting the implementation of CDSS were reviewed.

Results: We found evidence that the use of medication-related CDSS improves clinical outcomes. Also, significant results were obtained regarding the reduction of prescription errors, and the improvement in quality and safety of medication prescribed.

Conclusion: The results of this study show that, although computer systems such as CDSS may cause errors, in most cases, it has helped to improve prescribing, reduce side effects and drug interactions, and improve patient safety. Although these systems have improved the performance of practitioners and processes, there has not been much research on the impact of these systems on patient outcomes.

Keywords: Clinical decision support system, Medication, Significant factors, Patient outcomes, Systematic review

Conflicts of Interest: None declared

Funding: This work was supported by the Tehran University of Medical Sciences, Tehran, Iran (grant number 94-01-31-28873).

*This work has been published under CC BY-NC-SA 1.0 license.

Copyright $\odot$ Iran University of Medical Sciences

Corresponding author: Dr Maryam Zahmatkeshan, m.zahmatkeshan@fums.ac.ir

1. Health Information Management Department, School of Allied Medical Sciences, Tehran University of Medical Sciences, Tehran, Iran

2. OIM Department, Aston Business School, Aston University, Birmingham B4 7ET, United Kingdom

3. Noncommunicable Diseases Research Center, School of Medicine, Fasa University of Medical Sciences, Fasa, Iran $\uparrow$ What is "already known" in this topic:

- CDSSs can help to reduce ADEs, medication errors, DDIs, improve patient safety, and medicine prescriptions.

- CDSSs have the potential to promote practitioners' performance.

- DSS can lead to improved care and patient safety.

$\rightarrow$ What this article adds:

-Studies have shown that DSS has led to improvements in drug-related activities

- The integration of CDSS with other systems, in particular $\mathrm{CPOE}$, is one of their key success factors, helping to enhance the effectiveness of the system.

- The participation of key personnel in the system development is also one of the key success factors of DSS system implementation

- Practitioners' performance has also been improved with the use of DSS

- Few studies have been conducted concerning the DSS effect on the outcomes of patients and economies, so it is recommended that further studies should be conducted in this regard.

- Almost all CDSS studies reported positive findings for clinical processes' outcomes. 
Cite this article as: Shahmoradi L, Safdari R, Ahmadi H, Zahmatkeshan M. Clinical decision support systems-based interventions to improve medication outcomes: A systematic literature review on features and effects. Med J Islam Repub Iran. 2021 (22 Feb);35:27. https://doi.org/10.47176/mjiri.35.27

\section{Introduction}

Recently, extensive attention has been paid to reduce medical error and in particular, medication errors (1) as one of the most common errors in medicine $(2,3)$. Medication error is one of the main concerns of health care (2). According to the Institute of Medic ine report, nearly 80000 people are admitted to hospital in the United States every year from whom, 7000 die as a result of medication errors that $32-69 \%$ of them are definitely or probably preventable (4). The consequences of medication errors, in addition to complications (adverse events) in patients, result in the imposition of financial burdens on the health care system (3), in such a way that it harms at least 1.5 million people a year and adds $\$ 3.5$ billion to the hospital costs (2).

Medication errors often occur during prescribing procedures $(5,6)$. One study reported that the incidence of prescription error was 3 to 99 errors per 1000 prescriptions in hospitalized patients, leading to adverse events (ADEs) (6), and drug-drug interactions (DDIs) (3) that by accessing timely information and having a sufficient knowledge base, such as using the computer physician order entry system (CPOE) system, CDSS, or both (1) are potentially preventable (7).

It seems that one of the most important strategies to reduce errors is to simplify the work procedures and limit paperwork (5).

Information technology (IT), by automating tasks and monitoring actions, can reduce workload and increase productivity; therefore, it can reduce errors (8), improve patient safety (3) and also solve human problems (7). As a result, the use of IT-based programs has attracted the attention of many healthcare settings $(2,3)$. CDSS as one of the IT-based interventions has been known as a promising strategy to prevent medication errors (9-15).

It has also been considered as one of the most effective and efficient tools for improving prescription, avoiding adverse events, and optimizing correct drug dosing (16). Computerized decision support through drug recommendations, drug-allergy checks, and DDIs advice can help to select a correct drug (17). Hunt et al. defined computer-based: "clinical decision-making programs designed to specifically assist in matching the characteristic features of each patient with a computerized information base to provide patient-specific evaluation or advice to be sent to the clinician" (18). In this study, we the term CDSS means the computerized physician order entry, the clinical decision support system, or electronic prescription.

DSS compliance with recommendations will enhance the ability to change behavior significantly, appropriately, and consistently. Thus, DSS may result in the appropriate entree to information, thus evidence use, clinical decisionmaking, and enhanced care quality. In addition, studies have shown that DSS, by reducing side effects, in addition to savings cost, increases the efficiency of patient care and saves the time of physicians (14). DSS can also collect information for easy examination, counseling, and provision of alternative suggestions that are not immediately become apparent to a clinical specialist. Therefore, one of the most important goals of CDSS is improving the quality of care and paying attention to safety features (19).

To our best knowledge, a number of systematic reviews (SRs) has been performed on CDSS impacts, but they have only reviewed a particular aspect of medication, such as drug prescription and management (20-23), ADEs (24), therapeutic drug monitoring and dosing (25), DDIs (3), medication dosing assistants (26), reduction of prescription errors (27), reduction of unsafe prescription (28), medication safety $(29,30)$ and assisting in changing prescription practice (31). Many studies have also been conducted on the factors affecting the implementation of CDSS and several factors have been identified $(3,31-45)$. Therefore, in the present systematic literature review, we aimed to; comprehensively examine the effects of CDSS on more areas of medicine (reducing ADEs, DDIs, medication errors, prescription improvement, medication adherence, dosing, medication safety, and monitoring) rather than focusing on a particular aspect, to assess the CDSS impact on the performance of practitioner and outcomes of the patient, and finally to identify the most effective factors affecting the implementation of CDSS to help new developers.

\section{Methods}

\section{Search strategy}

PubMed, Web of Science, EMBASE, ProQuest, Scopus, besides databases of the Cochrane Library, were searched until 15 February 2017. The searches were not limited by language (studies in other languages were omitted due to incompatibility with the aim of this study).

The search strategy was based on a combination of the following two concepts: CDSS and significant factors affecting the implementation of CDSS. In this regard, the relevant systematic reviews were identified and then screened for inclusion.

The search query for the PubMed database is as follows: 1- ("systematic review" OR "meta analysis")

2- ("Decision Support System" OR "Clinical Decision Support System" OR "Clinical Decision Support" OR (Decision Support AND Clinical) OR (Support AND Clinical Decision))

3- (Achievement OR "success factors" OR "system success" OR "effective systems" OR "effectiveness of CDS systems" OR "critical factor" OR "key features" OR "features critical" OR Effect OR "features effective" OR effectiveness OR "Impact Assessment" OR Influence OR improvement OR quality OR safety OR efficacy OR "quality assurance" OR Enhancing OR development OR "Cost effectiveness" OR “cost-effectiveness") 


\section{4- 1 AND 2 AND 3}

\section{Selection of studies}

The search results were entered into the EndNote software, and the duplicates were removed and re-checked manually. The articles were then screened based on the titles and abstracts. A total of 665 articles was identified. By reviewing the full text of the articles, 98 papers were eventually included in our study (Fig. 1).

\section{Inclusion and exclusion criteria}

The systematic reviews assessed the CDSS efficiency in the field of medication were included in this review, including prescription, dosing, reducing medication errors, drug monitoring, Rx CDSS, medication management, medication safety, ADE, drug allergy, and DDIs. We included studies if they had; 1) assessed CDSSs (including clinical decision support system, electronic prescription, and computerized physician order entry system) that had been implemented in the field of medication such as; medication prescription, reducing medication errors, ADEs, drug-allergy checking, drug dosing support, and etc., and 2) evaluated significant factors affecting CDSS implementation. We excluded non-systematic review studies, commentaries, opinion papers, editorials, conference proceedings, summaries etc.

\section{Review procedures and data extraction}

We extracted data to summarize the key features of systematic reviews, including information about the researcher and publication year, research objective, assessed outcomes, and the review's results, as well as information about significant factors affecting CDSS implementation in the included studies.

Three thousand three hundred electronic records (after eliminating copies) were recognized using a combination of search techniques, and then they were examined for eligibility. First, all titles and abstracts were screened by two reviewers independently to distinguish related investigations on the basis of the present research aims. For a full review, 665 hypothetically eligible works were chosen among the citations. In the next stage, to be included in the final review, the full-text papers independently were reviewed in detail based on the above-mentioned inclusion criteria. Any disagreement was resolved either through discussion or involving a third reviewer. In order to handle citations, Endnote version X7 was applied.

\section{Classification of interventions and research outcomes}

The system was classified in terms of its correlation with medication in which a system was implemented, and our intended results were examined. In this review, the interest outcomes, in turn, were classified as the process outcomes (e.g., prescription, drug-drug interaction, drug adherence, etc.), patient outcomes, and significant factors affecting the implementation of CDSS.

\section{Results}

\section{Description of the studies}

PRISMA flow diagrams of included and excluded studies are shown in Figure 1. In total, 4815 publications were obtained with the search strategy, from which 3300 studies

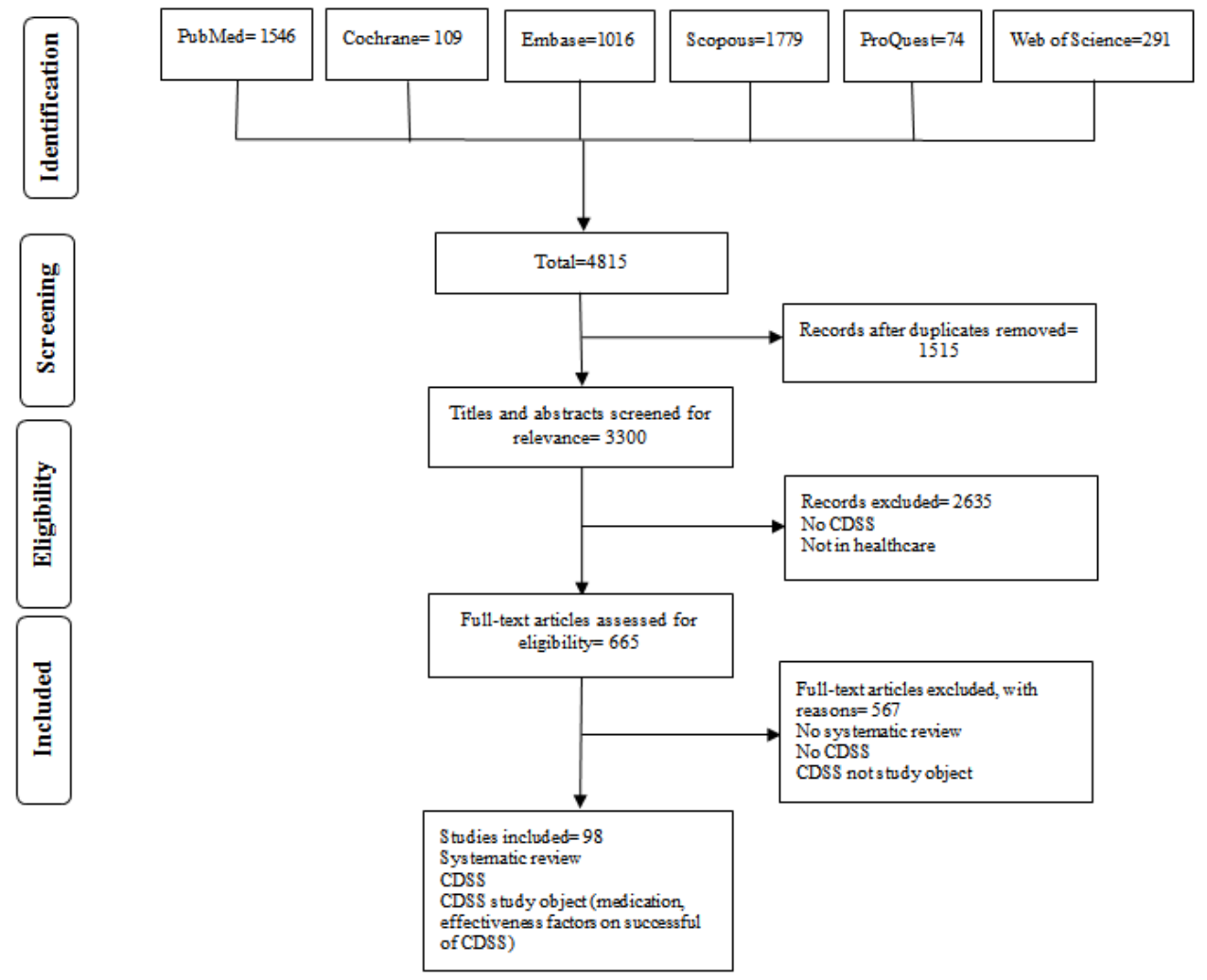

Fig. 1. Flow diagram of included and excluded studies 
remained after the duplication removal. We screened the titles and abstracts and also reviewed the full text of 665 articles. Finally, 98 articles met the inclusion criteria from which 86 were medicated-related, and 13 had reported the successful system implementations.

About a third $(27 / 85,31.7 \%)$ of the articles were focused on prescription $(14,23,32,40,46-68)$, eight reviews had evaluated interventions which were aimed at ADEs $(24,69-$ $75)$, four studies had followed the drug dosing $(25,76-78)$, nine reviews were focused on medication error reduction $(22,27,71,74,79-85)$, five reviews were about medication management $(1,20,86-88)$, five reviews had discussed medication practice (89-93), six studies had assessed the effect of system on medication use (94-99), four reviews were about medication safety $(28-30,100)$, two reviews were on medication monitoring $(25,101)$ one review was about medication adherence (102), one study had assessed the impact of DDIs (13), thirteen reviews were focused on the effects of CDSS on practitioners' performance and outcomes of patients $(21,26,103-113)$ and thirteen reviews had analyzed the significant factors affecting CDSS implementation (35-38, 43, 107, 114-120).

\section{Synthesis of evidence (interventions' Efficiency)}

In this part, study results were classified based on medication-related processes, patient outcomes, besides significant factors affecting the implementation.
Impact on processes of prescribing: Of twenty-seven studies investigating prescribing-condition, twenty-four studies showed positive effects such as prescription improvement, improvements in appropriateness of drug prescription, reduction in prescription errors, optimizing prescriptions, and reducing unsafe or unnecessary prescription $(14,23,32,40,46-52,55,57-68)$, and also three studies demonstrated the effectiveness of CDSS on prescription improvement that were not convincing (53) and required more investigation $(54,56)$.

Impact on adverse drug events (ADES): Three out of eight studies showed an improvement in reducing drug side effects $(24,71,74)$. Results of other studies have shown that using integrated DSS with CPOE prevent prescription of medications that cause side effect (69). Predicting ADE in clinical settings (72), and reducing ADE by $50 \%$ using COPE were among other benefits of this system (73). Other studies either did not show any changes in ADE rate or showed a non-conclusive effect of the system on ADE $(121,122)$. This information is given in Table 1 .

Impact on drug dosing: As presented in Table 2, In this category, studies reported that CCDSS could help to improve the care process through drug monitoring and dosing (25), increase the initial dose of the drug with computerized recommendations, reduce the time spending in hospital (77, 78 ) and control the treatment faster through dose adjustment (76).

Impact on the medication-related processes

Table 1. The effect of CDSS on ADEs

\begin{tabular}{|c|c|c|c|}
\hline References & CDSS focus ( study objective) & Effect measures & Main findings \\
\hline$(24)$ & $\begin{array}{l}\text { The relationship between CPOE with CDS and } \\
\text { the occurrence of an adverse drug event (ADE) }\end{array}$ & Decreased ADEs & $80 \%$ decrease in ADEs by using CPOE with CDS \\
\hline (69) & $\begin{array}{l}\text { Identification of automated/non-automated sys- } \\
\text { tems that can eliminate/reduce prescriptions } \\
\text { that may cause ADEs at the patient level and } \\
\text { their effectiveness }\end{array}$ & $\begin{array}{l}\text { Eliminate/reduce pre- } \\
\text { scriptions }\end{array}$ & $\begin{array}{l}\text { Various systems, including CPOE with DSS can re- } \\
\text { duce/eliminate prescription of medications that cause } \\
\text { ADEs. However, little evidence exists for supporting } \\
\text { that. To show the benefits of such systems in medical } \\
\text { care, further studies are required. }\end{array}$ \\
\hline (70) & $\begin{array}{l}\text { Assessing the effect of computerized laboratory } \\
\text { alerts on lowering ADEs rate and process out- } \\
\text { comes }\end{array}$ & $\begin{array}{l}\text { Promotion of choosing } \\
\text { clinical outcomes and } \\
\text { process outcomes }\end{array}$ & $\begin{array}{l}\text { No evidence exists about the usefulness and benefits of } \\
\text { computerized clinical alerts. However, there was some } \\
\text { improvement in process outcomes, including changes in } \\
\text { laboratory behaviors and prescribing behavior. There- } \\
\text { fore, more evidence is needed to prove the usefulness of } \\
\text { such systems in electronic medical records. }\end{array}$ \\
\hline (71) & $\begin{array}{l}\text { Assessing the effect of CPOE on elimina- } \\
\text { tion/decrease in medicine errors and ADE }\end{array}$ & $\begin{array}{l}\text { Elimination/decrease in } \\
\text { medicine errors and } \\
\text { ADE }\end{array}$ & $\begin{array}{l}\text { Findings showed that automated prescription and deci- } \\
\text { sion support system could be useful in the elimina- } \\
\text { tion/decrease in medicine errors and ADE in clinical set- } \\
\text { tings such as hospitals. }\end{array}$ \\
\hline$(72)$ & $\begin{array}{l}\text { Assessing various clinical alerts such as phar- } \\
\text { macy and laboratory signals currently used to } \\
\text { measure ADEs in hospital }\end{array}$ & $\begin{array}{l}\text { Promoting ADEs' de- } \\
\text { tection }\end{array}$ & $\begin{array}{l}\text { The results showed that clinical alerts such as pharmacy } \\
\text { and laboratory signals had been improved to identify } \\
\text { ADEs. However, more research on this subject is needed } \\
\text { to assess the use of such signals and CDS systems in dif- } \\
\text { ferent settings and analyze the system economically. }\end{array}$ \\
\hline (73) & $\begin{array}{l}\text { Detecting factors that are most effective in the } \\
\text { elimination/reduction of medication error and } \\
\text { evaluating the effect of CPOE in the elimina- } \\
\text { tion/reduction of preventable ADEs. }\end{array}$ & $\begin{array}{l}\text { Substantial decrease in } \\
\text { medication errors and } \\
\text { preventable ADEs }\end{array}$ & $\begin{array}{l}\text { More than } 50 \% \text { use of CPOE to decrease preventable } \\
\text { ADEs and medication errors }\end{array}$ \\
\hline (74) & $\begin{array}{l}\text { Measuring the cost-effectiveness of CPOE and } \\
\text { its capability to eliminate/reduce preventable } \\
\text { ADEs and medication errors }\end{array}$ & $\begin{array}{l}\text { Elimination/reduction } \\
\text { of preventable ADEs } \\
\text { and medication errors }\end{array}$ & $\begin{array}{l}\text { The combination of CPOE and decision support systems } \\
\text { can eliminate/reduce SDEs and medication errors }\end{array}$ \\
\hline$(75)$ & $\begin{array}{l}\text { Measuring the capability and economic useful- } \\
\text { ness of drug interaction detection software } \\
\text { (DIS) in elimination/reduction of ADEs }\end{array}$ & $\begin{array}{l}\text { ADEs' rate did not } \\
\text { change }\end{array}$ & $\begin{array}{l}\text { The outcomes of DIS (benefits, consequences, and eco- } \\
\text { nomic usefulness) and its effect on drug safety were not } \\
\text { detected. }\end{array}$ \\
\hline
\end{tabular}


Table 2. The effect of CDSS on drug dosing

\begin{tabular}{lll}
\hline References & CDSS focus (study objective) & Effect measures \\
\hline$(25)$ & $\begin{array}{l}\text { Evaluating the effect of CCDSS on } \\
\text { therapeutic drug monitoring and dos- }\end{array}$ & $\begin{array}{l}\text { Therapeutic drug monitoring and } \\
\text { dosing (TDMD) process improved }\end{array}$
\end{tabular}
therapeutic drug monitoring and dososing (TDMD) process improved ing (TDMD)

Assessing the capability of a computerized decision-making system in anticoagulant treatment

The effect of electronic advice on medication dosing

Evaluating the computerized medication dosing compared to non-computerized medication dosing
The computerized decision-making system improved dose adjustment

Major reduction in the toxicity of the drug, an increase in serum concentration and primary, dosing and shorter treatment time and hospitalization, thus, no effect on side effects.

Main findings

CCDSS can improve the therapeutic drug monitoring and dosing (TDMD) process, especially vitamin $\mathrm{K}$ and insulin dosing. However, CCDSS should be developed further and then it should be assessed through different studies using different research methods, particularly in terms of drug safety and patient outcomes. CCDSS can improve the therapeutic drug monitoring and dosing (TDMD) process, especially vitamin $\mathrm{K}$ and insulin dosing.

Findings referred to the ability of CDSS in adjusting the dose of anticoagulant

Computerized medication dosing had many benefits, including a major reduction in the toxicity of drugs, an increase in serum concentration and primary, dosing, and shorter treatment time and hospitalization, thus, no effect on the side effects.

Computerized medication dosing has many benefits, including increased serum concentrations, reduced hospitalization, and significant reduction of side effects
Impact on medication errors: Almost half of the studies (44\%) showed that, CDSS system, particularly when integrated with $\mathrm{CPOE}$, lead to a reduction of medication error
$(27,74,80,84)$. Other studies have pointed to the effectiveness of electronic prescribing in the reduction of medication error and ADE (71). Moreover, HIT especially DSS,

Table 3. The effect of CDSS on medication errors

\begin{tabular}{|c|c|c|c|}
\hline References & $\begin{array}{c}\text { CDSS focus } \\
\text { ( study objective) }\end{array}$ & Effect measures & Main findings \\
\hline (79) & $\begin{array}{l}\text { Assessing the effect of different in- } \\
\text { terventions on reduction of medica- } \\
\text { tion errors in critical care units }\end{array}$ & Reduction of medication errors & $\begin{array}{l}\text { Clinical decision making (SSCD) support system decreased } \\
\text { medication errors by } 67 \% \text {. However, there is not much evi- } \\
\text { dence to suggest that such systems can reduce medication } \\
\text { errors. }\end{array}$ \\
\hline$(80)$ & $\begin{array}{l}\text { Assessing the effect of different in- } \\
\text { terventions on reduction of medica- } \\
\text { tion errors in NICUs }\end{array}$ & Reduction of medication errors & $\begin{array}{l}\text { CPOE with a decision support system, medication errors, } \\
\text { and ISs may decrease medication errors }\end{array}$ \\
\hline$(22)$ & $\begin{array}{l}\text { Evaluating the effects of Decision } \\
\text { Support System (DSS) in the health } \\
\text { care }\end{array}$ & $\begin{array}{l}\text { improving the care quality and pa- } \\
\text { tient safety, including elimina- } \\
\text { tion/reduction of medication and } \\
\text { clinical errors, increasing the eco- } \\
\text { nomic efficiency, and increase the } \\
\text { knowledge of staffs }\end{array}$ & $\begin{array}{l}\text { Decision-making support system (DSS) increased compli- } \\
\text { ance with standard care and medication guidelines and also } \\
\text { helps healthcare professionals to eliminate/reduce medica- } \\
\text { tion and clinical errors. It also increased economic efficiency } \\
\text { and consequently increased the quality of care. }\end{array}$ \\
\hline (27) & $\begin{array}{l}\text { Assessing the effect of different in- } \\
\text { terventions on reduction of medicine } \\
\text { errors in children's wards }\end{array}$ & Reduction of medication errors & $\begin{array}{l}\text { Medication errors in pediatric wards will be reduced if cor- } \\
\text { rect and standard definitions are to be used, and also as- } \\
\text { sessing economic efficiency would also help to achieve de- } \\
\text { sired outcomes }\end{array}$ \\
\hline (71) & $\begin{array}{l}\text { Evaluating the risk of medication er- } \\
\text { ror and ADE by CPOE. }\end{array}$ & $\begin{array}{l}\text { Decrease in medicine error and } \\
\text { ADE risk }\end{array}$ & $\begin{array}{l}\text { A computerized prescription system is an effective tool that } \\
\text { can eliminate/reduce medication errors and ADEs in clinical } \\
\text { settings }\end{array}$ \\
\hline (74) & $\begin{array}{l}\text { Assessing the advantages and barri- } \\
\text { ers to the implementation of the } \\
\text { CPOE system in clinical settings, } \\
\text { and also assessing the effects of the } \\
\text { system in ADEs and medication er- } \\
\text { rors }\end{array}$ & $\begin{array}{l}\text { Decrease in medical errors and } \\
\text { ADEs, }\end{array}$ & $\begin{array}{l}\text { The combination of CPOE and CDSS systems can poten- } \\
\text { tially eliminate/reduce medication errors and ADEs. The un- } \\
\text { willingness of healthcare professionals and the high imple- } \\
\text { mentation costs are among the barriers }\end{array}$ \\
\hline (84) & $\begin{array}{l}\text { Assessing the effect of CPOE on pa- } \\
\text { tient safety }\end{array}$ & $\begin{array}{l}\text { CPOE system has a better effect } \\
\text { on medication errors and ADEs } \\
\text { when is used concurrently with } \\
\text { CDSS resulting in increased pa- } \\
\text { tient safety }\end{array}$ & $\begin{array}{l}\text { Significant reduction in medication errors and ADEs were } \\
\text { not seen when a CPOE system alone was implemented; how- } \\
\text { ever, the combination of CPOE and CDSS had a greater im- } \\
\text { pact on medication errors' reduction and increased patient } \\
\text { safety }\end{array}$ \\
\hline (82) & $\begin{array}{l}\text { Evaluating the health information } \\
\text { technology impacts on quality, effi- } \\
\text { ciency, and cost-effectiveness of } \\
\text { care }\end{array}$ & $\begin{array}{l}\text { Information technology increased } \\
\text { the adherence to care based on } \\
\text { guidelines, improved monitor- } \\
\text { ing/surveillance, and reduced } \\
\text { medicine errors. }\end{array}$ & $\begin{array}{l}\text { The majority of research has been conducted on CDS and } \\
\text { electronic health record systems. Several interventions influ- } \\
\text { enced the quality of care, such as increasing adherence to } \\
\text { care based on guidelines, improving monitoring/surveil- } \\
\text { lance, and reducing medicine errors }\end{array}$ \\
\hline (85) & $\begin{array}{l}\text { Studying the features of electronic } \\
\text { Patient Medication Record (ePMR), } \\
\text { including alerts and patient safety } \\
\text { measures during the prescribed time } \\
\text { at the pharmacy }\end{array}$ & $\begin{array}{l}\text { Patient Medication Record } \\
\text { (ePMR) was effective in alerting } \\
\text { staffs about clinical risks }\end{array}$ & $\begin{array}{l}\text { The features of the electronic Patient Medication Record } \\
\text { (ePMR), including alerts and patient safety measures, were } \\
\text { effective in alerting staff about clinical risks during the pre- } \\
\text { scribed time. There were also some problems, including false } \\
\text { alerts and performance inconsistencies. More study is } \\
\text { needed on this subject in different countries and settings. }\end{array}$ \\
\hline
\end{tabular}


has helped to improve the quality of care by improving disease assessment and compliance with clinical guidelines as well as reducing medication errors (82). DSS models have helped the physicians in selecting collect systems to achieve significant outcomes such as reduction of medical and medication errors (22). However, a study showed that interventions could not exclusively be effective in reducing medication errors (79), as are displayed in Table 3.

Impact on medication management: In regard to the effects of DSS on medication management, as presented in Table 4, studies have shown that such systems promote the quality of care and improve medication management (86). The use of DSSs that offer reminders and feedback is beneficial in improving medication use and different behaviors related to medication management (1). However, few studies have been conducted on patient safety threats or monitoring of side effects (20).

Medication practice: Almost all studies have shown the effect of DSS on the medication interventions, outcomes improvement, drug safety and reducing medication errors (91), promotion of professional activity, change in the field of alcohol and other drugs (AOD) using of reminders or

Table 4. The effect of CDSS on medication management

\begin{tabular}{|c|c|c|c|}
\hline References & CDSS focus ( study objective) & Effect measures & Main findings \\
\hline (1) & $\begin{array}{l}\text { Evaluating the effects of computerized systems } \\
\text { (reminders or feedback) to support medication } \\
\text { management of patient safety and medication } \\
\text { management }\end{array}$ & $\begin{array}{l}\text { Enhanced patient safety and ad- } \\
\text { herence to medication regimen, } \\
\text { enhanced medication manage- } \\
\text { ment, enhanced generic pre- } \\
\text { scribing of medication }\end{array}$ & $\begin{array}{l}\text { Computerized systems (reminders or feedback) } \\
\text { can enhance medication management. Factors that } \\
\text { affect implementation should also be considered }\end{array}$ \\
\hline (20) & $\begin{array}{l}\text { Exploring the effects of different intervention } \\
\text { such as medication management in ambulatory } \\
\text { care on patient safety }\end{array}$ & $\begin{array}{l}\text { In general, no risk to patient } \\
\text { safety was found }\end{array}$ & $\begin{array}{l}\text { There is no evidence to suggest that, implementa- } \\
\text { tion of electronic medication management sys- } \\
\text { tems in ambulatory settings can potentially cause } \\
\text { risks or harms to patients }\end{array}$ \\
\hline$(86)$ & $\begin{array}{l}\text { Exploring the effect of medication management } \\
\text { information technology (MMIT) on all medi- } \\
\text { cine management phases }\end{array}$ & $\begin{array}{l}\text { Enhanced prescribing behavior, } \\
\text { adherence to medication advice, } \\
\text { and reduced costs }\end{array}$ & $\begin{array}{l}\text { MMIT enhanced medication management. The } \\
\text { care quality was improved by approximately half } \\
\text { of the MMIT interventions; however, little re- } \\
\text { search has evaluated clinical outcomes }\end{array}$ \\
\hline (87) & $\begin{array}{l}\text { Exploring the effects of multifaceted interven- } \\
\text { tions in the improvement of depression out- } \\
\text { comes in primary care }\end{array}$ & $\begin{array}{l}\text { Promote more active medica- } \\
\text { tion management }\end{array}$ & $\begin{array}{l}\text { Factors, including qualified care managers, pa- } \\
\text { tient support system, patient education, continu- } \\
\text { ous monitoring, and decision support system is } \\
\text { important in medication management }\end{array}$ \\
\hline (88) & $\begin{array}{l}\text { Exploring the effects of health information tech- } \\
\text { nology on all stages of the medication manage- } \\
\text { ment process (drug prescribing, ordering, com- } \\
\text { munication, dispensing, administration, and } \\
\text { monitoring as well as education and reconcilia- } \\
\text { tion). }\end{array}$ & $\begin{array}{l}\text { Moderate to significant im- } \\
\text { provement in care with the im- } \\
\text { plementation of MMIT }\end{array}$ & $\begin{array}{l}\text { Studies that have been investigating the cost-ef- } \\
\text { fectiveness and clinical outcomes of the MMIT } \\
\text { system had ambiguous results. However, some } \\
\text { qualitative studies have found different percep- } \\
\text { tions of MMIT effects and outcomes. }\end{array}$ \\
\hline
\end{tabular}

Table 5. The effect of CDSS on Medication practice

\begin{tabular}{lll}
\hline References & CDSS focus (study objective) & \multicolumn{1}{c}{ Effect measures } \\
\hline$(89)$ & $\begin{array}{l}\text { Identifying electronic decision } \\
\text { support systems that directly } \\
\text { support pharmacists in the hos- } \\
\text { pital or community settings }\end{array}$ & Enhanced medication therapy \\
& $\begin{array}{l}\text { Exploring the implementation } \\
\text { of clinical guidelines in pharma- } \\
\text { cies }\end{array}$ & CDSS had a significant effect on the outcomes \\
& & \\
& $\begin{array}{l}\text { Evaluating the health IT impact } \\
\text { on the quality, safety, and effi- } \\
\text { ciency of healthcare }\end{array}$ & $\begin{array}{l}\text { Positive effect on patient safety reduced medica- } \\
\text { tion errors }\end{array}$
\end{tabular}

(92) Improved adherence to guidelines, increased overall prescription time, increased in unattended alerts

Improved adherence to guidelines, increased overall prescription time, increased in unattended alerts

Identifying the most effective strategies related to alcohol and other drugs (AOD)
The use of reminders had a moderate to significant effect on process outcomes. Improved prescribing and adherence to guidelines. Major improvement in professional practice and client outcomes. Reminders should be used in general medicine clinics to improve alcohol counseling. Feedback indicated $1-16 \%$ improvement in professional practice.

\begin{abstract}
Main findings
Very little evidence exists in the literature that explores electronic decision support system activities for pharmacy or pharmacists, in comparison to the countless related literature for healthcare.

Currently, very little evidence exists to prove that, implementation of clinical guidelines has a positive impact on outcomes of patients. No evidence exists to suggest the best implementation method

Many studies referred to the benefits of using CDSS and CPOE. Many studies that have explored the effect of implementing health IT on patient improving patient safety and reducing medication errors

Not much evidence exist to demonstrate that CPOE systems improve safety and decrease costs in outpatient situations. Nevertheless, many studies have found evidence in favor of improved adherence to guidelines, increased overall prescription time, increased in unattended alerts

The results suggested the use of $d$ reminders and feedback to improve AOD. More specific studies are required to explore the use of reminders and feedback in AOD-related activities in clinical settings.
\end{abstract}


feedback (93), and reduction of the cost (92). These are presented in Table 5.

Impact on medication usage: Table 6 shows that half of the studies have been examining the interventions that facilitate the proper use of polypharmacy in elderly people, which indicated the improvement in reduction of incorrect prescription $(94,98,99)$. Furthermore, strategies such as electronic alarms have been proven to be effective in the better use of medications, especially in the short term (95). Studies have shown that the decision-making support system and the use of medication were the most common practice and strategies $(56 \%),(96)$.

Impact on medication safety: Various studies have been conducted on drug safety and the use of different approaches, which indicated that DSS, in particular when integrated with CPOE, has been associated with the reduced drug errors and improved drug use (30). DSS leads to improvements in care processes and reduction of drug errors and positively effects drug dosing and patient outcomes (29). Also, these interventions have a significant impact on reducing the risks to safety, which consequently leads to a significant reduction in drug errors, especially during the interaction between the doctor and the pharmacist (28) as presented in Table 7.

Impact on monitoring practices: Nieuwlaat et al. concluded that, for therapeutic drug monitoring and dosing (TDMD), CCDSSs help to improve the process of care, but there are no clear results about their effect on patient outcomes(25). Fischer et al. showed that, regarding the role of HIT interventions in monitoring laboratory drugs for ambulatory settings, there are not many studies and conclusive evidence; therefore, more research is needed to clarify it (101). This information is presented in Table 8.

Impact on medication adherence and Drug-drug interactions (DDIs): Table 9 indicate that studies on drug adherence and drug interactions, IT-based interventions, especially DSS, have been the most effective interventions to improve drug adherence and drug interactions $(13,102)$.

\section{Impact on practitioners' performance and patient out-} comes

In Table 10, thirteen studies showed the positive impact of DSS systems on the quality and efficiency of care (21, 26, 103-113). CPOE and DSS have had a positive effect on patient safety outcomes (113), and have played an im-

Table 6. The effect of CDSS on Medication usage

\begin{tabular}{|c|c|c|c|}
\hline References & CDSS focus (study objective) & Effect measures & Main findings \\
\hline$(94)$ & $\begin{array}{l}\text { Evaluating effective interven- } \\
\text { tions in reducing medication- } \\
\text { problems and enhancing the } \\
\text { suitable application of }\end{array}$ & $\begin{array}{l}\text { Substantial decrease in medi- } \\
\text { cation errors and ADEs. }\end{array}$ & $\begin{array}{l}\text { Interventions for improving suitable polypharmacy, like phar- } \\
\text { maceutical care, led to clinically significant improvement are } \\
\text { yet to be proved; however, the interventions are believed to re- } \\
\text { duce inappropriate prescribing and medication errors }\end{array}$ \\
\hline
\end{tabular}
polypharmacy in the elderly. Exploring interventions to en- Decreased antibiotic prescribhance medicine use in con- ing. Enhanced recommended trolled care organizations laboratory drug monitoring. (MCOs). Specifically in the US Increased overall medication managed care setting.

Examining the interventions' efficiency to decrease low-value treatment.

Assessing interventions' impacts in order to assist consumers in using medications safely and efficiently.
Improvements in medicines use and adherence. Reduction in adverse events and improved clinical outcomes.

Decreased inappropriate poly-pharmacy. Enhanced adherence to medication.

Decreased inappropriate prescribing
Summarizing effective interventions in reducing medication- problems and enhancing the suitable use of polypharmacy in the elderly

Evaluating the systematic reviews on enhancing the suitable use of polypharmacy in the elderly
Many studies indicate the changing of drug use in the US man. aged care setting. Computerized alerts can improve short-term outcomes. Few well-designed studies are yet to test their effect on patient outcomes.

A substantial rise in anti-depressant adherence

Reduction in inappropriate prescription acid-suppressive medications.

The studies on decision support targeting drug use were mos common. The most significant influence on low-value treatment is multidimensional interventions that consider both patient and provider functions in medication overuse. Althougl there are comparatively high data on the effectiveness of clinical decision support, it requires more investigation and devel. opment.

The most-reported outcome was adherence to the medicatior regimen.

The results of this overview can be used by decision-makers ir implementing interventions for improving medication use by consumers to realize the best ones for enhancing particular outcomes.

Interventions for improving suitable polypharmacy, like phar maceutical care leading to significant improvement clinically are still to be demonstrated. They seem, however, useful in de. creasing unsuitable prescriptions.

Cochrane reviews summarized in this article emphasize the lack of intervention research on enhancing the proper polypharmacy use in old patients. Generally, the interventions mentioned ir the review revealed benefits in this regard on the basis of a per. ceived reduction in unsuitable prescriptions.

Nevertheless, if the interventions may result in significant clinical improvements concerning hospital admissions, medicationassociated issues, and life quality of patients are yet to be established. Guidance associated with intervention enhancement, as. sessment, and report would assist in further future research. 
Table 7. The effect of CDSS on Medication safety

CDSS focus (study objective)

Evaluating the effect of IT interven-

tion in the improvement of drug

safety in primary care.

The effect of CDSS on drug safety.

Improving drug safety by using Reduced medication error CPOE and CDSSs.

Exploring different interventions to prevent drug safety in hospitals.

rates. medication administration,
Effect measures

CDS reduced the rate of inappropriate

prescriptions

Decrease in medicine error

(dose /prescription). en-

hancement in medicine

dosing, care process, and outcomes related to medicine/drug

Improvement in safety, and reduction of drug errors

Main findings
In general, IT interventions are believed to decrease medica-
tion errors. However, IT interventions are not without safety
hazards.
hazards.

CDSS decreased medicine error and enhanced the care process; however, it did not improve outcomes significantly CDSS, reminders, or medicine alerts may enhance courses of care outcomes; CDSS associated with medicine dosing has the potential to improve patient outcomes.

CDSSs and CPOE may dramatically decrease medicine error and provide further vital benefits associated with the use of medicine.

Evidence suggests the effectiveness of interventions in reducing medicine errors and negative drug measures. However, the results of a number of studies contradict this.

\begin{tabular}{|c|c|c|c|}
\hline References & CDSS focus (study objective) & Effect measures & Main findings \\
\hline$(25)$ & $\begin{array}{l}\text { Evaluating the effects of CCDSS } \\
\text { effects on therapeutic drug moni- } \\
\text { toring and dosing (TDMD) in } \\
\text { randomized controlled trials } \\
\text { (RCTs) }\end{array}$ & $\begin{array}{l}\text { Improved therapeutic drug } \\
\text { monitoring and dosing } \\
(\mathrm{TDMD})\end{array}$ & $\begin{array}{l}\text { CDSS can improve TDMD, particularly in the dosing of insulin } \\
\text { and vitamin K; however, it needs to be further developed }\end{array}$ \\
\hline$(101)$ & $\begin{array}{l}\text { Identifying studies that have in- } \\
\text { vestigated the HIT interventions } \\
\text { to enhance laboratory observing } \\
\text { of chosen high-risk drugs in the } \\
\text { ambulatory situation. }\end{array}$ & $\begin{array}{l}\text { The was not enough evi- } \\
\text { dence to demonstrate the } \\
\text { HIT impact in enhancing la- } \\
\text { boratory observing of partic- } \\
\text { ular high-risk drugs for am- } \\
\text { bulatory patients }\end{array}$ & $\begin{array}{l}\text { Overall, practically half of the randomized controlled experi- } \\
\text { ments demonstrated major enhancements in the laboratory ob- } \\
\text { serving of particular high-risk drugs. However, The was not } \\
\text { enough evidence to demonstrate the effect of HIT in improving } \\
\text { laboratory observing of particular high-risk drugs for patients } \\
\text { in ambulatory settings; thus, more studies are required. }\end{array}$ \\
\hline \multicolumn{4}{|l|}{$100 t e$} \\
\hline References & CDSS focus ( study objective) & Effect measures & Main findings \\
\hline$(102)$ & $\begin{array}{l}\text { Assessing the most effective fac- } \\
\text { tors that influence patients' adher- } \\
\text { ence to medication therapy in pa- } \\
\text { tients with osteoporosis }\end{array}$ & $\begin{array}{l}\text { Patient adherence to drugs } \\
\text { improved }\end{array}$ & $\begin{array}{l}\text { Findings indicated that factors such as making dosing regi- } \\
\text { men simpler, patient decision making support system, patient } \\
\text { education, and electronic prescription system were most ef- } \\
\text { fective in patients' drug adherence in patients with osteopo- } \\
\text { rosis. However, the patient decision making support system } \\
\text { was the most effective factor. }\end{array}$ \\
\hline (13) & $\begin{array}{l}\text { Evaluating the effects and charac- } \\
\text { teristics of computerized interven- } \\
\text { tions on the outcomes of DDI }\end{array}$ & $\begin{array}{l}\text { Increasing DDI alert adher- } \\
\text { ence and clinical outcomes } \\
\text { with computerized interven- } \\
\text { tions }\end{array}$ & $\begin{array}{l}\text { The results showed that DDI alert adherence and clinical out- } \\
\text { comes were increased by computerized interventions. The ef- } \\
\text { fect of DDI on the medication-related issues such as drug pre- } \\
\text { scription, administration, and dispense at decision making } \\
\text { time }\end{array}$ \\
\hline
\end{tabular}

portant role in the various aspects of drug management, patient outcomes, and cost-cutting (112). Bright et al. reported that CDSS is less effective in clinical and economic activities, and its success depends on providing the correct information at the right moment to the right person (109). With the integration of DSS with workflow, these systems can help improve professional performance in promoting preventive care, medication order, and adherence to guidelines. Computer reminders can lead to improvements in drug interaction warnings, drug prescriptions, and test orders $(105,108)$. Also, some studies have shown that DSS can improve the performance of experts by up to $76 \%$ using reminders and up to $66 \%$ using drug prescription or dosage systems, and also it can improve patient outcomes by up to $13 \%$ (107). In almost all of these studies, the impact of DSS on patient outcomes has been less widely considered therefore, we can hardly be conclusive about its impact.

Significant factors affecting CDSS implementation: In this section, we describe the most important factors affecting the implementation of CDSS mentioned in the studies as presented in Table 11.

In general, the findings of this study showed that most studies (about 30\%) have considered key employees' participation in the system development process $(42,117,118$, 123), support of key managers and personnel, training and monitoring of the system in the early stages of implementation $(41,42,117,118)$, and the need for the predictive role of specific systems or organizational features $(31,33$, $35,40)$ as the most important factors. Approximately $23 \%$ of the studies have considered factors such as integration of the system with other systems such as $\operatorname{CPOE}(3,43,114)$ and organizational workflow $(3,43,114)$, and also implementing the system at the right time $(34,35,44)$, and about $15 \%$ of the studies have considered the infrastructure and adequate resources $(42,123)$ as effective factors. In other studies, factors such as the provision of advice for practitioners and patients, and providing CDSS by the developers of the system (43), factors of the human, organizational and technology (37), user groups' perceptions of significant 
Table 10. The effect of CDSS on practitioners' performance and patient outcomes

\begin{tabular}{|c|c|c|}
\hline References & CDSS focus ( study objective) & Effect measures \\
\hline (107) & $\begin{array}{l}\text { Assessing the effectiveness of } \\
\text { CDSSs on practitioner performance } \\
\text { and patient outcomes. }\end{array}$ & $\begin{array}{l}\text { Improve practitioner performance, diagno- } \\
\text { sis, disease prevention and management, and } \\
\text { drug dosing and prescribing. }\end{array}$ \\
\hline$(106)$ & $\begin{array}{l}\text { Assessing the CDSS system impact } \\
\text { on the performance of clinician and } \\
\text { outcomes of patient }\end{array}$ & $\begin{array}{l}\text { improved clinical performance in drug dos- } \\
\text { ing, } \\
\text { disease prevention }\end{array}$ \\
\hline$(105)$ & $\begin{array}{l}\text { Evaluating the effect of a CDSS on } \\
\text { the performance of practitioners } \\
\text { and outcomes of patients in hospi- } \\
\text { tals }\end{array}$ & $\begin{array}{l}\text { Positive effect on practitioner performance } \\
\text { and patient outcome when combined with } \\
\text { systems of drug prescription and preventive } \\
\text { care reminder }\end{array}$ \\
\hline
\end{tabular}

Evaluating CDSS impacts on the performance of clinicians and outcomes of patients

Identifying ways to promote the use of antibiotics through an electronic prescribing system in a clinical setting

Assessing the CDSS impact on clinical outcomes, workload and effectiveness, health care courses, cost, and patient satisfaction,

Evaluating the care courses and outcomes using decision support system and computer reminders at the care point

Exploring the relationship between HIT and medical practices and other health care and providing information for stakeholders to promote and maximize the uptake of HIT.

Investigating the health IT effects on safety outcomes of patients in all clinical areas.
Improved dosing of toxic drugs, quality of preventive care, and patient outcome

Improved process of care and patient outcomes

Improved the process of care in medication dosing and management, alerts/reminders, management, adherence to guidelines and diagnosis

The health care process was enhanced by CDSSs/KMSs

Enhanced dosing and choosing of antibiotics, enhanced adherence to clinical guidelines, reducing the use of antibiotics to prevent antibiotic resistance, reduced prescription and prescription errors, and reduction in negative medicine measures, duration of hospital stay, and drug hypersensitivity and reaction

Positive effect on drug prescribing, preventive care, and clinical outcomes

enhanced prescribing behaviors, minor to modest care enhancements

Considerable increase in physician compliance to drug type and dosage recommendation, reduction in pharmacists' interventions for incorrect drug doses.

Positive impact on patient safety outcomes

\section{Main findings}

CDSS system improves practitioner performance. Cower, more studies are required to demonstrate the effects of such systems on patient health. CDSS may enhance the care quality

CDSS can have a positive effect on the performance of practitioners and outcomes of patients when combined with preventive care reminder systems and drug prescribing system. CDSS is constantly developing and changing, so newer CDSS systems probably have a greater effect on the performance of practitioners and outcomes of patients

Various CDSSs can improve practitioners' performance. In order to evaluate their impacts and costefficiency on outcomes of patients, in particular, more research is required.

CCDSSs improved the process of care measures and patient outcomes. There was not enough evidence to support patient benefit, harms, and costeffectiveness in adopting CCDSSs for managing drug treatment

CCDSSs improved the care course; however, outcomes of patients were not evaluated

Various types of CDSSs/KMSs (systems established locally and commercially) are efficient in healthcare process development in different settings. They're not much evidence on the effectiveness of CDSSs in clinical outcomes and costs.

Clinical decision support systems and practitioner performance are important; however, new technologies like them can create new challenges such as data inaccuracies, which may affect the workflow. Therefore, there is a need for further development of such systems to suit the needs of users

CPOE and CDS were the main interventions, but various aspects of drug management were also included. Clinical assessment such considers various factors, including processes, cost-effectiveness, and outcomes in order to better educate the public

CDSSs are effective at improving the health care process in diverse settings. However, more evidence is needed for clinical, economic, workload, or efficiency outcomes.

Computer reminders significantly improved care at the point of care. Insignificant improvements across a range of processes. However, in order to implement clinical information systems, the prospect of offering computerized reminders at the care point signifies a substantial drive. In order to ascertain crucial elements that facilitate or predict care promotion, further research is needed.

The results of this study may help the adoption of HIT/HIS and increase the uptake of evidence-based practice using HIT/HIS.

There is a need for further research in different sceneries to comprehend better how health IT influences patients. factors affecting the implementation, technical and organizational support (119), the structure of healthcare organizations, information and decision processes, people policies, tasks, and incentives (120) have contributed to the success of the system. 
Table 11. Significant factors affecting CDSS implementation

\begin{tabular}{|c|c|}
\hline References & Result (critical factors in the implementation of CDSS) \\
\hline (37) & Human, organization, and technology factors \\
\hline (123) & $\begin{array}{l}\text { External context, the need for supportive laws and regulation, proper standards, policies and incentives, right organization } \\
\text { condition, matching innovations with workflows, staffs' knowledge and beliefs, processes and systems }\end{array}$ \\
\hline$(32,115,123)$ & Integrating systems in current organizational workflow \\
\hline (119) & Users' perceptions of significant factors in implementation, and technical and organizational support \\
\hline$(3,43,114)$ & The systems integration into other systems \\
\hline (43) & Reasons for counseling, providing simultaneous advice to practitioners and patients, as well as \\
\hline$(42,117,118,123)$ & Engagement of key personnel in the system development and implementation processes \\
\hline $\begin{array}{l}(41,42,117,118) \\
(120)\end{array}$ & $\begin{array}{l}\text { Support of managers and key personnel, training and monitoring the system in the early stages of implementation } \\
\text { structure of healthcare organizations; information and decision processes; work policies and staffs' incentives }\end{array}$ \\
\hline (38) & Quality of the system and information, and usability of the system \\
\hline$(32,115)$ & Hardware availability, technical support, and appropriate clinical messages \\
\hline (42) & Features of the system itself and a supportive and appropriate environment to improve the quality of patient services \\
\hline$(31,33,35,40)$ & The need for the predictive role of specific systems or organizational features \\
\hline (45) & Appropriate attitude and skills of user with good leadership, appropriate IT environment and effective communication \\
\hline (114) & $\begin{array}{l}\text { Implementation of interventions by the system, the lack of user control over output, the retrieval of data from the electronic } \\
\text { medical record and CPOE }\end{array}$ \\
\hline$(34,35,44)$ & Level of computer interface, provision of advice at the right time for decision making \\
\hline (36) & Provision of an automated decision support system \\
\hline (39) & Executive support, understanding the business, IT-business relations, and leadership \\
\hline$(42,123)$ & Appropriate and right infrastructure and resources \\
\hline$(118)$ & Users' experience and training \\
\hline
\end{tabular}

\section{Discussion}

\section{Main findings}

Previous studies have often measured the effects of CDSS on a particular area of medication, such as a prescription. However, to the best of our knowledge, these systematic reviews have not evaluated a wide range of areas. Therefore, this overview provides a comprehensive picture of the effects of CDSS on more aspects of the medication, such as reducing ADEs, DDIs and drug errors, improving prescription, drug adherence and dosage, drug safety and monitoring rather than focusing on a particular aspect. The present study also evaluated the CDSS impact on the performance of practitioners and outcomes of patients; finally, it identified the most effective factors affecting the implementation of CDSS to help the new developers.

We found evidence that the use of medication-related CDSS improves clinical outcomes. Also, significant results were obtained regarding the reduction of prescription errors and the improvement in quality and safety of medication prescribed. These findings are in line with the results of other studies $(33,124-132)$. In relation to ADEs, significant improvements have been achieved in the clinical results of ADEs, which has been associated with clinical outcomes in other studies (133-136). Whereas in King et al.'s study, similar effects of ADEs were not found (137). Ranji et al. also showed that the possibility of error occurrence would be reduced if such programs are applied carefully, and the production of safer care systems is more closely followed (138). In regard to the reduction of medication errors, as with other studies, our findings showed that CDSS is one of the most effective strategies to reduce the risks of medication errors $(137,139-145)$. Our findings showed that CDSS could help physicians to determine the optimal dosage of the drug in proportion to the patient's need, reduce unwanted side effects of the drug, and increase the benefits of treatment, which are consistent with the existing literature (146-150). Furthermore, when CPOE systems are integrated into a CDSS to alert doctors and other health care providers, the reduction of laboratory or medical errors and improvements in medication safety are significant. This is in accordance with the result of other studies $(126,151$, 152). Kausha et al. showed that IT interventions might not be able to fully resolve drug safety issues, but they seem to be an effective approach (142). As seen in studies of Bindoff et al. and McCoy et al. (153, 154), our findings showed that CDSS systems could facilitate and improve medication management.

Drug-drug interactions are one of the most important and preventable issues through these systems. Tilson et al. reported that a process should be used to develop and maintain a standard set of DDIs for CDSS (155). Böttiger et al. concluded that, when paired with a clinical decision support system for DDIs, SFINX can be a useful instrument if employed (156). Saverno et al. showed that a comprehensive system, such as a CDSS, is necessary to improve the identification of potential DDIs (157). In our study, like the studies of Cox et al. (158) and Mahoney et al. (159), there were improvements in medication dosing and monitoring.

In regards to the effectiveness of CDSS in clinical practice and patient outcomes, studies have shown CDSSs are effective in changing the care processes and can improve performance (e.g., right drug dosing, appropriate prescribing of medication). However, few studies have demonstrated that CDSSs can improve patient outcomes $(33,160$, 161). The results of some studies about improving patient outcomes are still unclear $(162,163)$. Moreover, Main et al. study indicated that the implementation of CDSS is timeconsuming, complex and costly (164).

This study carefully evaluated critical factors that affect the implementation of CDSS from multiple perspectives. Different studies have also pointed to various factors. Participation and involvement of physicians in the process of CDSS development, from the beginning, play a significant role in accepting the usefulness of that system $(165,166)$. Our research results, like Varonen's study, showed that having a positive view about the simple use of CDSS and understanding the benefits of patient outcomes as well as the usefulness of CDSS will cause physicians to use the 
system more, and vice versa, a negative view of doctors about CDSS is a barrier to focusing on the patient, or clinical work (167).

We found that one of the main obstacles to the implementation of CDSS was the threat of physician-patient communication, which was related to the physician's computer skills.

One study found that when physicians pay attention to the computer, patients' emotions are ignored. Patients believed that, if doctors maintain eye contact with them, the use of computer systems does not disturb their communication (168). The results of Trivedi et al.'s study showed that training doctors before the implementation of CDSS is one of the most important and effective strategies for optimal use of CDSS (169). Furthermore, to ensure a better transition period, organizations should emphasize education and training programs at the pre-implementation stage (170-172). In addition, they must familiarize people with the capabilities of the system and software before the actual implementation of the system. They should also change the attitude of personnel towards the tool. The relevance of educational and training programs about computer skills, physicians' pattern of use, and availability of on-site information technology, and the provision of individual support for doctors can also be significant strategies (168, 169, 173). Moreover, proper training for the end-users and peerto-peer training has been shown to have a positive impact on CDSS implementation (174).

Several studies showed that automated CDSS should provide advice at the right time and at the point of care for decision making $(34,35,44)$; while Berlin et al. found that only in $41 \%$ of cases (175). The results of some studies showed that some doctors prefer to see recommendations before the patient's visit or at the end of their working day. This difference can be justified by changing clinical practices and workflows. Therefore, the timing of the CDSS recommendations should be consistent with the doctor's workflow $(165,176)$. With the direct support of IT, physicians can respond quickly when they encounter problems with the use of the system. The policies and incentives, engagement of key personnel, adequate infrastructure and resources, organizational readiness, the coordination of innovations with workflows, and individuals' knowledge, beliefs, as well as processes and systems, are important factors that should be considered in the implementation of the system in the healthcare settings (177).

Studies showed that users are looking for a system that is both functional and responsive to their professional needs. In these studies, users indicated that factors such as design and technical support, interoperability, appropriate content, productivity, and resources are important and should be considered (172, 178-181). The system should also be implemented in such a way that it facilitates the exchange of information between organizations (interoperability) (182, 183). Davis (184) refers to Technology Acceptance Model and states that the most common factors in accepting the use of information and communication technology by healthcare professionals include the system's usefulness (a clear understanding of the benefits of innovation) and ease of use, similar to the results of other studies $(173,185-187)$.
Meanwhile, the engagement of leaders and key personnel also helps to understand the usefulness and user-friendliness of the system (186), although this result was not found in Marcy's study (188). Similar to the results of Gagnon et al.'s (117) study, Gravel (189) showed that time constraint is one of the most important obstacles to the adoption of ICT and shared decision-making implementation in clinical practice.

Ross et al. showed that inadequate coordination between ICT applications and clinical workflow is another factor that leads to the unsuccessful implementation of systems (116), and these findings are in line with the results of other studies $(45,190,191)$. Other barriers to the implementation of systems that were stated by Reisman included the users' failure to use CDSS or the rejection of system recommendations by experts (191). Issues related to characteristics of system-specific and organizational and personal issues affect the acceptance of new technologies by physicians (192)

Studies showed that systems that perform the task automatically have a better performance than those that the system's users initiate them, and this is consistent with Kawamoto and Lobach 's findings (36), but Hemens et al.'s study did not find this result (21). Adaptability and cost were two important factors that Lee et al. pointed out in e-health intervention (177).

Given the importance of preventing medication-related errors and safety issues, the use of CDSS systems is one of the main strategies for improving patient safety, practitioners' performance, and the quality and efficiency of care. There is also a need for the development of decision support tools that are consistent with a clinicians' workflow that is also customized, as they can have a positive effect on efficiency and cost-effectiveness.

\section{Strengths and limitations of the review}

One of the most important features of this study was that there was no specific language restriction in this study (studies in other languages were omitted due to incompatibility with the aim of this study). We almost tried to examine more aspects of the medication rather than focusing on a particular aspect.

This study has some limitations. One of these limitations was that related studies such as the grey literature and conferences might have been lost and may be relevant papers have been excluded due to the search terms. However, there are valuable conferences that might be even more relevant to the implementation of CDSS than those in grey literature. A variety of internationally-appropriated keywords and MeSH headings were utilized within areas of the search; however, some relevant papers may have been overlooked.

\section{Implications for further research}

Based on the findings of our review, this study highlights future directions in this area of research. Healthcare organizations would be better to be familiar with the system, its capabilities, and its applications in order to make a valuable and extensive investment in this area. Also, system providers can help improve system performance by providing and 
designing user-friendly CDSS systems and knowledgebased tools to make the system use more effective. Educational programs before the implementation of the system for key users are other important factors that health care organizations should pay attention to. System integration into other systems such as CPOE, EHR, e-prescribing, and workflow and interoperability is also one of the key issues in the development of the system, which will be facilitated according to terminology and standards. Healthcare organizations can continue to encourage the use of this system by providing strong and appropriate infrastructure. However, more studies are needed to examine the effectiveness of CDSS on patient safety outcomes, to determine success factors in its implementation and also to investigate the effect of CDSSs on economic in clinical settings especially in the medication-related fields.

\section{Conclusion}

The results of this study show that, although computer systems such as CDSS may cause errors, in most cases, it has helped to improve prescribing, reduce side effects and drug interactions, and improve patient safety. Although these systems have improved the performance of practitioners and processes, there has not been much research on the impact of these systems on patient outcomes. Moreover, the factors such as the participation of key personnel in the process of development and implementation of the system, training, and monitoring of the system in the early stages of implementation, and the integration of the system with other systems, in particular CPOE, have been the most important factors influencing the success of CDSS implementation.

\section{Conflict of Interests}

The authors declare that they have no competing interests.

\section{References}

1. Bennett JW, Glasziou PP. Computerised reminders and feedback in medication management: a systematic review of randomised controlled trials. Med J Austral. 2003;178(5):217-22.

2. Marfo K. Evaluation of medication errors via a computerized physician order entry system in an inpatient renal transplant unit. 2011.

3. Nabovati E, Vakili-Arki H, Taherzadeh Z, Saberi MR, Medlock S, AbuHanna A, et al. Information Technology-Based Interventions to Improve Drug-Drug Interaction Outcomes: A Systematic Review on Features and Effects. J Med Syst. 2017;41(1):12.

4. Donaldson MS, Corrigan JM, Kohn LT. To err is human: building a safer health system: National Academies Press; 2000.

5. Kazemi A, Ellenius J, Pourasghar F, Tofighi S, Salehi A, Amanati A, et al. The effect of computerized physician order entry and decision support system on medication errors in the neonatal ward: experiences from an Iranian teaching hospital. J Med Syst. 2011;35(1):25-37.

6. Sintchenko V, Coiera E, Gilbert GL. Decision support systems for antibiotic prescribing. Curr Opin Infect Dis. 2008;21(6):573-9.

7. Goldstein MK, Hoffman BB, Coleman RW, Tu SW, Shankar RD, O'Connor M, et al. Patient safety in guideline-based decision support for hypertension management: ATHENA DSS. J Am Med Inform Assoc. 2002;9(Supplement_6):S11-S6.

8. Yazdani A, Ghazisaeedi $\bar{M}$, Ahmadinejad N, Giti M, Amjadi H, Nahvijou A. Automated Misspelling Detection and Correction in Persian Clinical Text. J Digit Imaging. 2019:1-8.

9. Bennett JW, Glasziou PP. Computerised reminders and feedback in medication management: a systematic review of randomised controlled trials. Med J Aust. 2003;178(5):217-+.
10. Forni A, Chu HT, Fanikos J. Technology utilization to prevent medication errors. Curr Drug Saf. 2010;5(1):13-8.

11. Kim J, Chae YM, Kim S, Ho SH, Kim HH, Park CB. A study on user satisfaction regarding the clinical decision support system (CDSS) for medication. J Healthc Inform Res. 2012;18(1):35-43.

12. Lee Y, Bae M, Park J, Choi C, Bae S, Chae Y. Evaluation of the effects of the CDSS for drug prescription for hospitals. J Korea Soc Health Infor Stat. 2007;32(2):89-98.

13. Nabovati E, Vakili-Arki H, Taherzadeh Z, Saberi MR, Medlock S, Abu-Hanna A, et al. Information Technology-Based Interventions to Improve Drug-Drug Interaction Outcomes: A Systematic Review on Features and Effects. J Med Syst. 2017;41(1):12.

14. Sintchenko V, Magrabi F, Tipper S. Are we measuring the right endpoints? Variables that affect the impact of computerised decision support on patient outcomes: a systematic review. Med Inform Int Med. 2007;32(3):225-40.

15. Yazdani A, Safdari R, Ghazisaeedi M, Beigy H, Sharifian R. Scalable architecture for telemonitoring chronic diseases in order to support the CDSSs in a common platform. Acta Inform Med. 2018;26(3):195.

16. Berner ES. Clinical decision support systems: Springer; 2007.

17. Akçura MT, Ozdemir ZD. Drug prescription behavior and decision support systems. Decis Support Syst. 2014;57:395-405.

18. Hunt DL, Haynes RB, Hanna SE, Smith K. Effects of computer-based clinical decision support systems on physician performance and patient outcomes: a systematic review. Jama. 1998;280(15):1339-46.

19. Goldstein MK, Hoffman BB, Coleman RW, Tu SW, Shankar RD, O'Connor M, et al. Patient safety in guideline-based decision support for hypertension management: ATHENA DSS. J Am Med Inform Assoc. 2002;9(Supplement 6):S11-S6.

20. Carling CLL, Kirkehei I, Dalsbo TK, Paulsen E. Risks to patient safety associated with implementation of electronic applications for medication management in ambulatory care - a systematic review. BMC Med Inform Decis Mak. 2013;13.

21. Hemens BJ, Holbrook A, Tonkin M, Mackay JA, Weise-Kelly L, Navarro T, et al. Computerized clinical decision support systems for drug prescribing and management: A decision-maker-researcher partnership systematic review. Implement Sci. 2011;6(1).

22. Yaghoubi Ashrafi M, Karami M, Safdari R, Nazeri A. Selective overview on decision support systems: Focus on HealthCare. Life Sci J. 2013;10(SPL.ISSUE10):348-55.

23. Yourman L, Concato J, Agostini JV. Use of computer decision support interventions to improve medication prescribing in older adults: a systematic review. Am J Geriatr Pharmacother. 2008;6(2):119-29.

24. Wolfstadt JI, Gurwitz JH, Field TS, Lee M, Kalkar S, Wu W, et al. The effect of computerized physician order entry with clinical decision support on the rates of adverse drug events: a systematic review. J Gen Intern Med. 2008;23(4):451-8.

25. Nieuwlaat R, Connolly SJ, Mackay JA, Weise-Kelly L, Navarro T, Wilczynski NL, et al. Computerized clinical decision support systems for therapeutic drug monitoring and dosing: A decision-makerresearcher partnership systematic review. Implement Sci. 2011;6(1).

26. Sahota N, Lloyd R, Ramakrishna A, Mackay JA, Prorok JC, WeiseKelly L, et al. Computerized clinical decision support systems for acute care management: A decision-maker-researcher partnership systematic review of effects on process of care and patient outcomes. Implement Sci. $2011 ; 6(1)$.

27. Rinke ML, Bundy DG, Velasquez CA, Rao S, Zerhouni Y, Lobner K, et al. Interventions to reduce pediatric medication errors: a systematic review. Pediatrics. 2014;134(2):338-60.

28. Lainer M, Mann E, Sonnichsen A. Information technology interventions to improve medication safety in primary care: a systematic review. International journal for quality in health care : Int J Qual Health Care. 2013;25(5):590-8.

29. Jia P, Zhang L, Chen J, Zhao P, Zhang M. The effects of clinical decision support systems on medication safety: An overview. PloS one. 2016;11(12).

30. Kaushal R, Shojania KG, Bates DW. Effects of computerized physician order entry and clinical decision support systems on medication safety - A systematic review. Arch Intern Med. 2003;163(12):1409-16.

31. Pearson S-A, Moxey A, Robertson J, Hains I, Williamson M, Reeve $\mathrm{J}$, et al. Do computerised clinical decision support systems for prescribing change practice? A systematic review of the literature (1990-2007). BMC Health Serv Res. 2009;9(1):154.

32. Baysari MT, Lehnbom EC, Li L, Hargreaves A, Day RO, Westbrook 
JI. The effectiveness of information technology to improve antimicrobial prescribing in hospitals: A systematic review and metaanalysis. Int J Med Inf. 2016;92:15-34.

33. Garg AX, Adhikari NK, McDonald H, Rosas-Arellano MP, Devereaux P, Beyene J, et al. Effects of computerized clinical decision support systems on practitioner performance and patient outcomes: a systematic review. Jama. 2005;293(10):1223-38.

34. Huff S, McClurec R, Parkerc C, Rochac R, Abarbaneld R, Beardd N, et al. Modeling guidelines for integration into clinical workflow. Medinfo. 2004:174.

35. Kawamoto K, Houlihan CA, Balas EA, Lobach DF. Improving clinical practice using clinical decision support systems: a systematic review of trials to identify features critical to success. Bmj. 2005;330(7494):765.

36. Kawamoto K, Lobach DF. Clinical decision support provided within physician order entry systems: a systematic review of features effective for changing clinician behavior. AMIA Ann Symp Proc. 2003:361-5.

37. Kilsdonk E, Peute LW, Jaspers MWM. Factors influencing implementation success of guideline-based clinical decision support systems: A systematic review and gaps analysis. Int J Med Inf. 2017;98:56-64.

38. Kilsdonk E, Peute LW, Knijnenburg SL, Jaspers MW. Factors known to influence acceptance of clinical decision support systems. Stud Health Technol Inform. 2011;169:150-4.

39. Luftman J. Assessing business-IT alignment maturity. Strategies for information technology governance. 2004;4:99.

40. Mollon B, Chong J, Jr., Holbrook AM, Sung M, Thabane L, Foster G. Features predicting the success of computerized decision support for prescribing: a systematic review of randomized controlled trials. BMC Med Inform Decis Mak. 2009;9:11.

41. Moxey A, Robertson J, Newby D, Hains I, Williamson M, Pearson SA. Computerized clinical decision support for prescribing: provision does not guarantee uptake. J Am Med Inform Assoc. 2010;17(1):25-33.

42. Randell R, Dowding D. Organisational influences on nurses' use of clinical decision support systems. Int J Med Inform. 2010;79(6):41221.

43. Roshanov PS, Fernandes N, Wilczynski JM, Hemens BJ, You JJ, Handler SM, et al. Features of effective computerised clinical decision support systems: Meta-regression of 162 randomised trials. BMJ (Online). 2013;346(7899).

44. Saleem JJ, Patterson ES, Militello L, Render ML, Orshansky G, Asch SM. Exploring barriers and facilitators to the use of computerized clinical reminders. J Am Med Inform Assoc. 2005;12(4):438-47.

45. Yusof MM, Kuljis J, Papazafeiropoulou A, Stergioulas LK. An evaluation framework for Health Information Systems: human, organization and technology-fit factors (HOT-fit). Int J Med Inform. 2008;77(6):386-98.

46. Tawadrous D, Shariff SZ, Haynes RB, Iansavichus AV, Jain AK, Garg $\mathrm{AX}$. Use of clinical decision support systems for kidney-related drug prescribing: a systematic review. American journal of kidney diseases : the official. Am J Kidney Dis. 2011;58(6):903-14.

47. Robertson J, Walkom E, Pearson SA, Hains I, Williamsone M, Newby D. The impact of pharmacy computerised clinical decision support on prescribing, clinical and patient outcomes: a systematic review of the literature. Int J Pharm Pract. 2010;18(2):69-87.

48. Pearson SA, Moxey A, Robertson J, Hains I, Williamson M, Reeve J, et al. Do computerised clinical decision support systems for prescribing change practice? A systematic review of the literature (1990-2007). BMC Health Serv Res. 2009;9:154.

49. Iankowitz N, Dowden M, Palomino S, Uzokwe H, Worral P. The effectiveness of computer system tools on potentially inappropriate medications ordered at discharge for adults older than 65 years of age: a systematic review. JBI Libr Syst Rev. 2012;10(13):798-831.

50. Holstiege J, Mathes T, Pieper D. Effects of computer-aided clinical decision support systems in improving antibiotic prescribing by primary care providers: a systematic review. J Am Med Inform Assoc: JAMIA. 2015;22(1):236-42.

51. Al-Bahar F, Marriott J, Curtis C, Dhillon H. The effects of computeraided clinical decision support systems on antibiotic prescribing in secondary care: A systematic review. Int J Pharm Pract. 2015;23:24.

52. Schedlbauer A, Prasad V, Mulvaney C, Phansalkar S, Stanton W, Bates DW, et al. What evidence supports the use of computerized alerts and prompts to improve clinicians' prescribing behavior? J Am Med Inform Assoc: JAMIA. 2009;16(4):531-8.

53. Reckmann MH, Westbrook JI, Koh Y, Lo C, Day RO. Does
Computerized Provider Order Entry Reduce Prescribing Errors for Hospital Inpatients? A Systematic Review. J Am Med Inform Assoc. 2009;16(5):613-23

54. Opondo D, Eslami S, Visscher S, de Rooij SE, Verheij R, Korevaar $\mathrm{JC}$, et al. Inappropriateness of medication prescriptions to elderly patients in the primary care setting: a systematic review. PloS one. 2012;7(8):e43617.

55. Mitchell E, Sullivan F. A descriptive feast but an evaluative famine: systematic review of published articles on primary care computing during 1980-97. Br Med J. 2001;322(7281):279-82E.

56. Loganathan M, Singh S, Franklin BD, Bottle A, Majeed A. Interventions to optimise prescribing in care homes: systematic review. Age Ageing. 2011;40(2):150-62.

57. Delpierre C, Cuzin L, Fillaux J, Alvarez M, Massip P, Lang T. A systematic review of computer-based patient record systems and quality of care: more randomized clinical trials or a broader approach? International journal for quality in health care Int J Qual Health Care. 2004;16(5):407-16.

58. van Rosse F, Maat B, Rademaker CMA, van Vught AJ, Egberts ACG, Bollen CW. The Effect of Computerized Physician Order Entry on Medication Prescription Errors and Clinical Outcome in Pediatric and Intensive Care: A Systematic Review. Pediatrics. 2009;123(4):1184-90. 59. Shojania KG, Jennings A, Mayhew A, Ramsay C, Eccles M, Grimshaw J. Effect of point-of-care computer reminders on physician behaviour: a systematic review. Can Med Assoc J. 2010;182(5):E216E25.

60. Prgomet M, Georgiou A, Westbrook JI. The Impact of Mobile Handheld Technology on Hospital Physicians' Work Practices and Patient Care: A Systematic Review. J Am Med Inform Assoc: JAMIA. 2009;16(6):792-801.

61. Grindrod KA, Patel P, Martin JE. What interventions should pharmacists employ to impact health practitioners' prescribing practices? Ann Pharmacother. 2006;40(9):1546-57.

62. Black AD, Car J, Pagliari C, Anandan C, Cresswell K, Bokun T, et al. The impact of eHealth on the quality and safety of health care: a systematic overview. PLoS Med. 2011;8(1):e1000387.

63. Alldred David P, Kennedy M-C, Hughes C, Chen Timothy F, Miller $\mathrm{P}$. Interventions to optimise prescribing for older people in care homes. Cochrane Database Syst Rev [Internet]. 2016; (2). Available from: http://onlinelibrary.wiley.com/doi/10.1002/14651858.CD009095.pub3 /abstract

http://onlinelibrary.wiley.com/store/10.1002/14651858.CD009095.pub3/ asset/CD009095.pdf?v=1\&t=iyv7r6v2\&s=603c51ed805057f5d38ab65 $826 \mathrm{a} 8 \mathrm{~d} 773067 \mathrm{a} 696 \mathrm{c}$

64. Wagner B, Filice GA, Drekonja D, Greer N, MacDonald R, Rutks I, et al. Antimicrobial stewardship programs in inpatient hospital settings: A systematic review. Infect Control Hosp Epidemiol. 2014;35(10):1209-28.

65. Clyne B, Fitzgerald C, Quinlan A, Hardy C, Galvin R, Fahey T, et al. Interventions to Address Potentially Inappropriate Prescribing in Community-Dwelling Older Adults: A Systematic Review of Randomized Controlled Trials. J Am Geriatr Soc. 2016;64(6):1210-22. 66. Chauhan BF, Jeyaraman M, Mann AS, Lys J, Skidmore B, Sibley KM, et al. Behavior change interventions and policies influencing primary healthcare professionals' practice-an overview of reviews. Implement Sci. 2017;12(1)

67. Brown CL, Mulcaster H, Triffitt K, Husband AK, Slight SP. A systematic review of the types and causes of prescribing errors generated from using computerized provider order entry systems in both primary and secondary care. J Gen Intern Med. 2016;31(2):S108S9.

68. McDonagh MS, Peterson K, Winthrop K, Cantor A, Holzhammer B, Buckley D. Systematic evaluation of interventions to reduce overprescribing of antibiotics for acute respiratory tract infections. Pharmacoepidemiol Drug Saf. 2016;25:387-8.

69. van der Linden CM, Jansen PA, Grouls RJ, van Marum RJ, Verberne MA, Aussems LM, et al. Systems that prevent unwanted represcription of drugs withdrawn because of adverse drug events: a systematic review. Ther Adv Drug Saf. 2013;4(2):73-90.

70. Bayoumi I, Al Balas M, Handler SM, Dolovich L, Hutchison B, Holbrook A. The effectiveness of computerized drug-lab alerts: a systematic review and meta-analysis. Int J Med Inf. 2014;83(6):406-15.

71. Ammenwerth E, Schnell-Inderst P, Machan C, Siebert U. The effect of electronic prescribing on medication errors and adverse drug events: A systematic review. J Am Med Inform Assoc: JAMIA 
2008;15(5):585-600.

72. Handler SM, Altman RL, Perera S, Hanlon JT, Studenski SA, Bost JE, et al. A Systematic Review of the Performance Characteristics of Clinical Event Monitor Signals Used to Detect Adverse Drug Events in the Hospital Setting. J Am Med Inform Assoc. 2007;14(4):451-8.

73. Nuckols TK, Smith-Spangler C, Morton SC, Asch SM, Patel VM, Anderson LJ, et al. The effectiveness of computerized order entry at reducing preventable adverse drug events and medication errors in hospital settings: A systematic review and meta-analysis. Syst Rev. 2014;3(1).

74. Charles K, Cannon M, Hall R, Coustasse A. Can utilizing a computerized provider order entry (CPOE) system prevent hospital medical errors and adverse drug events? Perspect Health Inf Manag. $2014 ; 11$.

75. Wong K, Yu SK, Holbrook A. A systematic review of medication safety outcomes related to drug interaction software. J Popul Ther Clin Pharmacol. 2010;17(2):e243-55.

76. Chatellier G, Colombet I, Degoulet P. An overview of the effect of computer-assisted management of anticoagulant therapy on the quality of anticoagulation. Int J Med Inf. 1998;49(3):311-20.

77. Durieux P, Trinquart L, Colombet I, Nies J, Walton R, Rajeswaran A, et al. Computerized advice on drug dosage to improve prescribing practice. Cochrane Database Syst Rev. 2008(3):CD002894.

78. Gillaizeau F, Chan E, Trinquart L, Colombet I, Walton RT, RègeWalther M, et al. Computerized advice on drug dosage to improve prescribing practice. Cochrane Database Syst Rev [Internet]. 2013; (11). Available from: http://onlinelibrary.wiley.com/doi/10.1002/14651858.CD002894.pub3 /abstract

http:/onlinelibrary.wiley.com/store/10.1002/14651858.CD002894.pub3/ asset/CD002894.pdf?v=1\&t=izieh6ro\&s=6e602fd4164d4a3c31be80ff $7 \mathrm{ba} 1 \mathrm{~b} 427 \mathrm{f} 3008 \mathrm{a} 68$

79. Manias E, Williams A, Liew D. Interventions to reduce medication errors in adult intensive care: a systematic review. Br J Clin Pharmacol. 2012;74(3):411-23.

80. Manias E, Kinney S, Cranswick N, Williams A, Borrott N. Interventions to reduce medication errors in pediatric intensive care. Ann Pharmacother. 2014;48(10):1313-31.

81. Jia PL, Zhang PF, Li HD, Zhang LH, Chen Y, Zhang MM. Literature review on clinical decision support system reducing medical error. J Evid Based Med. 2014;7(3):219-26.

82. Chaudhry B, Wang J, Wu S, Maglione M, Mojica W, Roth E, et al. Systematic review: Impact of health information technology on quality, efficiency, and costs of medical care. Ann Intern Med. 2006;144(10):742-52.

83. O'Reilly D, Tarride JE, Goeree R, Lokker C, McKibbon KA. The economics of health information technology in medication management: a systematic review of economic evaluations. J Am Med Inform Assoc: JAMIA. 2012;19(3):423-38.

84. Zhu C, Lee J. The impact of computerized physician order entry implementation on patient safety: Lessons learned. J Am Pharm Assoc. 2016;56(3):e137.

85. Ojeleye O, Avery A, Gupta V, Boyd M. The evidence for the effectiveness of safety alerts in electronic patient medication record systems at the point of pharmacy order entry: a systematic review. BMC Med Inform Decis Mak. 2013;13.

86. McKibbon KA, Lokker C, Handler SM, Dolovich LR, Holbrook AM, O'Reilly D, et al. The effectiveness of integrated health information technologies across the phases of medication management: a systematic review of randomized controlled trials. J Am Med Inform Assoc

2012;19(1):22-30.

87. Williams Jr JW, Gerrity M, Holsinger T, Dobscha S, Gaynes B, Dietrich A. Systematic review of multifaceted interventions to improve depression care. Gen Hosp Psychiatry. 2007;29(2):91-116.

88. Furlan AD, McKibbon KA, Lokker C, Handler SM, Dolovich LR, Holbrook AM, et al. Enabling medication management through health information technology (Health IT). Evid Rep Technol Assess. 2011(201):1-951.

89. Calabretto JP, Warren J, Bird L. Pharmacy decision support: Where is it? A systematic literature review. Int J Pharm Pract. 2005;13(3):15763.

90. Watkins K, Wood H, Schneider CR, Clifford R. Effectiveness of implementation strategies for clinical guidelines to community pharmacy: a systematic review. Implement Sci : IS. 2015;10:151.

91. Jones SS, Rudin RS, Perry T, Shekelle PG. Health information technology: an updated systematic review with a focus on meaningful use. Ann Intern Med. 2014;160(1):48-54.

92. Eslami S, Abu-Hanna A, de Keizer NF. Evaluation of outpatient computerized physician medication order entry systems: a systematic review. J Am Med Inform Assoc: JAMIA. 2007;14(4):400-6.

93. Bywood PT, Lunnay B, Roche AM. Strategies for facilitating change in alcohol and other drugs (AOD) professional practice: A systematic review of the effectiveness of reminders and feedback. Drug Alcohol Rev. 2008;27(5):548-58.

94. Patterson SM, Hughes C, Kerse N, Cardwell CR, Bradley MC. Interventions to improve the appropriate use of polypharmacy for older people. Cochrane Database Syst Rev. 2012(5):Cd008165.

95. Lu CY, Ross-Degnan D, Soumerai SB, Pearson SA. Interventions designed to improve the quality and efficiency of medication use in managed care: A critical review of the literature - 2001-2007. BMC Health Serv Res. 2008;8.

96. Colla CH, Mainor AJ, Hargreaves C, Sequist T, Morden N Interventions Aimed at Reducing Use of Low-Value Health Services: A Systematic Review. Med Care Res Rev. 2016.

97. Ryan R, Santesso N, Lowe D, Hill S, Grimshaw J, Prictor M, et al. Interventions to improve safe and effective medicines use by consumers: an overview of systematic reviews. Cochrane Database Syst Rev. 2014;4:CD007768.

98. Patterson SM, Cadogan CA, Kerse N, Cardwell CR, Bradley MC, Ryan $\mathrm{C}$, et al. Interventions to improve the appropriate use of polypharmacy for older people. Cochrane Database Syst Rev. 2014;10:CD008165.

99. Cooper JA, Cadogan CA, Patterson SM, Kerse N. Interventions to improve the appropriate use of polypharmacy in older people: a Cochrane systematic review. BMJ Open. 2015;5(12):e009235.

100. Acheampong F, Anto BP, Koffuor GA. Medication safety strategies in hospitals - A systematic review. Int J Risk Saf Med. 2014;26(3):11731 .

101. Fischer SH, Tjia J, Field TS. Impact of health information technology interventions to improve medication laboratory monitoring for ambulatory patients: a systematic review. J Am Med Inform Assoc. 2010;17(6):631-6.

102. Hiligsmann M, Salas M, Hughes DA, Manias E, Gwadry-Sridhar FH, Linck $\mathrm{P}$, et al. Interventions to improve osteoporosis medication adherence and persistence: a systematic review and literature appraisal by the ISPOR Medication Adherence \& Persistence Special Interest Group. Osteoporos Int. 2013;24(12):2907-18.

103. Lobach D, Sanders GD, Bright TJ, Wong A, Dhurjati R, Bristow E, et al. Enabling health care decisionmaking through clinical decision support and knowledge management. Evid Rep Technol Assess (Full Rep). 2012(203):1-784

104. Johnston ME, Langton KB, Haynes RB, Mathieu A. Effects of computer-based clinical decision support systems on clinician performance and patient outcome. A critical appraisal of research. Ann Intern Med. 1994;120(2):135-42.

105. Jaspers MW, Smeulers M, Vermeulen H, Peute LW. Effects of clinical decision-support systems on practitioner performance and patient outcomes: a synthesis of high-quality systematic review findings. J Am Med Inform Assoc. 2011;18(3):327-34.

106. Hunt DL, Haynes RB, Hanna SE, Smith K. Effects of computerbased clinical decision support systems on physician performance and patient outcomes - A systematic review. JAMA. 1998;280(15):133946.

107. Garg AX, Adhikari NKJ, McDonald H, Rosas-Arellano MP Devereaux PJ, Beyene J, et al. Effects of computerized clinical decision support systems on practitioner performance and patient outcomes - A systematic review. J Am Med Assoc. 2005;293(10):1223-38.

108. Cresswell K, Majeed A, Bates DW, Sheikh A. Computerised decision support systems for healthcare professionals: An interpretative review. Inform Prim Care. 2012;20(2):115-28.

109. Bright TJ, Wong A, Dhurjati R, Bristow E, Bastian L, Coeytaux RR, et al. Effect of clinical decision-support systems: a systematic review. Ann Intern Med. 2012;157(1):29-43.

110. Shojania KG, Jennings A, Mayhew A, Ramsay CR, Eccles MP Grimshaw J. The effects of on-screen, point of care computer reminders on processes and outcomes of care. Cochrane Database Syst Rev. 2009(3):Cd001096

111. Jamal A, McKenzie K, Clark M. The impact of health information technology on the quality of medical and health care: a systematic review. The HIM journal. 2009;38(3):26-37. 
112. Cresswell K, Mozaffar H, Shah S, Sheikh A. Approaches to promoting the appropriate use of antibiotics through hospital electronic prescribing systems: a scoping review. Int J Pharm Pract. 2017;25(1):517.

113. Brenner SK, Kaushal R, Grinspan Z, Joyce C, Kim I, Allard RJ, et al. Effects of health information technology on patient outcomes: a systematic review. J Am Med Inform Assoc. 2016;23(5):1016-36.

114. Nies J, Colombet I, Degoulet P, Durieux P. Determinants of success for computerized clinical decision support systems integrated in CPOE systems: a systematic review. Proc AMIA Symp. 2006:594-8.

115. Moxey A, Robertson J, Newby D, Hains I, Williamson M, Pearson SA. Computerized clinical decision support for prescribing: Provision does not guarantee uptake. J Am Med Inform Assoc. 2010;17(1):25-33.

116. Ross J, Stevenson F, Lau R, Murray E. Factors that influence the implementation of e-health: a systematic review of systematic reviews (an update). Implement Sci. 2016;11.

117. Gagnon MP, Desmartis M, Labrecque M, Car J, Pagliari C, Pluye P, et al. Systematic Review of Factors Influencing the Adoption of Information and Communication Technologies by Healthcare Professionals. J Med Syst. 2012;36(1):241-77.

118. Alavi M, Joachimsthaler EA. Revisiting DSS implementation research: A meta-analysis of the literature and suggestions for researchers. MIS Q. 1992;16(1):95-113.

119. Gagnon MP, Nsangou ÉR, Payne-Gagnon J, Grenier S, Sicotte C. Barriers and facilitators to implementing electronic prescription: A systematic review of user groups' perceptions. J Am Med Inform Assoc. 2014;21(3):535-41.

120. Lluch M. Healthcare professionals' organisational barriers to health information technologies-a literature review. Int $\mathrm{J}$ Med Inf. 2011;80(12):849-62.

121. Brown CL, Mulcaster H, Triffitt K, Husband AK, Slight SP. A systematic review of the types and causes of prescribing errors generated from using computerized provider order entry systems in both primary and secondary care. J Gen Intern Med. 2016;31(2):S108S9.

122. Nuckols TK, Smith-Spangler C, Morton SC, Asch SM, Patel VM, Anderson LJ, et al. The effectiveness of computerized order entry at reducing preventable adverse drug events and medication errors in hospital settings: A systematic review and meta-analysis. Syst Rev. 2014;3(1).

123. Ross J, Stevenson F, Lau R, Murray E. Factors that influence the implementation of e-health: a systematic review of systematic reviews (an update). Implement Sci. 2016;11(1).

124. Bobb A, Gleason K, Husch M, Feinglass J, Yarnold PR, Noskin GA. The epidemiology of prescribing errors: the potential impact of computerized prescriber order entry. Arch Intern Med. 2004;164(7):785-92.

125. Curtain C, Peterson G. Review of computerized clinical decision support in community pharmacy. J Clin Pharm Ther. 2014;39(4):3438.

126. Kuperman GJ, Bobb A, Payne TH, Avery AJ, Gandhi TK, Burns G, et al. Medication-related clinical decision support in computerized provider order entry systems: a review. J Am Med Inform Assoc. 2007;14(1):29-40

127. Spinewine A, Schmader KE, Barber N, Hughes C, Lapane KL, Swine C, et al. Appropriate prescribing in elderly people: how well can it be measured and optimised? The Lancet. 2007;370(9582):173-84.

128. Stultz JS, Nahata MC. Computerized clinical decision support for medication prescribing and utilization in pediatrics. J Am Med Inform Assoc. 2012;19(6):942-53.

129. Tawadrous D, Shariff SZ, Haynes RB, Iansavichus AV, Jain AK, Garg AX. Use of clinical decision support systems for kidney-related drug prescribing: a systematic review. Am J Kidney Dis. 2011;58(6):903-14

130. Tesfaye WH, Castelino RL, Wimmer BC, Zaidi STR. Inappropriate prescribing in chronic kidney disease: A systematic review of prevalence, associated clinical outcomes and impact of interventions. Int J Clin Pract. 2017.

131. Trafton JA, Martins SB, Michel MC, Wang D, Tu SW, Clark DJ, et al. Designing an automated clinical decision support system to match clinical practice guidelines for opioid therapy for chronic pain Implement Sci. 2010;5(1):26.

132. Wagholikar KB, Hankey RA, Decker LK, Cha SS, Greenes RA, Liu $\mathrm{H}$, et al. Evaluation of the effect of decision support on the efficiency of primary care providers in the outpatient practice. J
Prim Care Commun Health. 2015;6(1):54-60.

133. Gurwitz JH, Field TS, Rochon P, Judge J, Harrold LR, Bell CM, et al. Effect of Computerized Provider Order Entry with Clinical Decision Support on Adverse Drug Events in the Long-Term Care Setting. J Am Geriatr Soc. 2008;56(12):2225-33.

134. Morimoto T, Gandhi T, Seger A, Hsieh T, Bates D. Adverse drug events and medication errors: detection and classification methods. Qual Saf Health Care. 2004;13(4):306-14.

135. Routledge PA, O'mahony M, Woodhouse K. Adverse drug reactions in elderly patients. Br J Clin Pharmacol. 2004;57(2):121-6.

136. Kane-Gill SL, Achanta A, Kellum JA, Handler SM. Clinical decision support for drug related events: moving towards better prevention. World J Crit Care Med. 2016;5(4):204.

137. King WJ, Paice N, Rangrej J, Forestell GJ, Swartz R. The effect of computerized physician order entry on medication errors and adverse drug events in pediatric inpatients. Pediatrics. 2003;112(3):506-9.

138. Ranji SR, Rennke S, Wachter RM. Computerised provider order entry combined with clinical decision support systems to improve medication safety: a narrative review. BMJ Qual Saf. 2014:bmjqs2013-002165.

139. Agrawal A. Medication errors: prevention using information technology systems. Br J Clin Pharmacol. 2009;67(6):681-6.

140. Bates DW, Teich JM, Lee J, Seger D, Kuperman GJ, Ma'Luf N, et al. The impact of computerized physician order entry on medication error prevention. J Am Med Inform Assoc. 1999;6(4):313-21.

141. Devine EB, Hansen RN, Wilson-Norton JL, Lawless NM, Fisk AW, Blough DK, et al. The impact of computerized provider order entry on medication errors in a multispecialty group practice. J Am Med Inform Assoc. 2010;17(1):78-84.

142. Kaushal R, Barker KN, Bates DW. How can information technology improve patient safety and reduce medication errors in children's health care? Arch Pediatr Adolesc Med. 2001;155(9):1002-7.

143. Keers RN, Williams SD, Cooke J, Walsh T, Ashcroft DM. Impact of interventions designed to reduce medication administration errors in hospitals: a systematic review. Drug Saf. 2014;37(5):317-32.

144. Potts AL, Barr FE, Gregory DF, Wright L, Patel NR. Computerized physician order entry and medication errors in a pediatric critical care unit. Pediatrics. 2004;113(1):59-63.

145. Raschke RA, Gollihare B, Wunderlich TA, Guidry JR, Leibowitz AI, Peirce JC, et al. A computer alert system to prevent injury from adverse drug events: development and evaluation in a community teaching hospital. Jama. 1998;280(15):1317-20.

146. Delaney BC, Fitzmaurice DA, Riaz A, Hobbs FR. Can computerised decision support systems deliver improved quality in primary care? BMJ. 1999;319(7220):1281.

147. Franke L, Avery A, Groom L, Horsfield P. Is there a role for computerized decision support for drug dosing in general practice? A questionnaire survey. J Clin Pharm Ther. 2000;25(5):373-7.

148. Helmons P, Grouls RJ, Roos A, Bindels A, Wessels-Basten S, Ackerman E, et al. Using a clinical decision support system to determine the quality of antimicrobial dosing in intensive care patients with renal insufficiency. Qual Saf Health Care. 2010;19(1):22-6.

149. Terrell KM, Perkins AJ, Hui SL, Callahan CM, Dexter PR, Miller DK. Computerized decision support for medication dosing in renal insufficiency: a randomized, controlled trial. Ann Emerg Med. 2010;56(6):623-9. e2.

150. Walton R, Harvey E, Dovey S, Freemantle N. Computerised advice on drug dosage to improve prescribing practice. Cochrane Database Syst Rev. 2001;1:CD002894.

151. Lehmann CU, Kim GR. Computerized provider order entry and patient safety. Pediatr Clin. 2006;53(6):1169-84.

152. Van Der Sijs H, Aarts J, Vulto A, Berg M. Overriding of drug safety alerts in computerized physician order entry. J Am Med Inform Assoc (JAMIA). 2006;13(2):138-47.

153. Bindoff I, Tenni P, Peterson G, Kang B, Jackson S. Development of an intelligent decision support system for medication review. J Clin Pharm Ther. 2007;32(1):81-8.

154. McCoy AB, Waitman LR, Gadd CS, Danciu I, Smith JP, Lewis JB, et al. A computerized provider order entry intervention for medication safety during acute kidney injury: a quality improvement report. Am J Kidney Dis. 2010;56(5):832-41.

155. Tilson H, Hines LE, McEvoy G, Weinstein DM, Hansten PD, Matuszewski $\mathrm{K}$, et al. Recommendations for selecting drug-drug interactions for clinical decision support. Am J Health Syst Pharm. 2016;73(8):576. 
156. Böttiger Y, Laine K, Andersson ML, Korhonen T, Molin B, Ovesjö ML, et al. SFINX - a drug-drug interaction database designed for clinical decision support systems. Eur J Clin Pharmacol. 2009;65(6):627-33.

157. Saverno KR, Hines LE, Warholak TL, Grizzle AJ, Babits L, Clark $\mathrm{C}$, et al. Ability of pharmacy clinical decision-support software to alert users about clinically important drug - drug interactions. J Am Med Inform Assoc. 2010;18(1):32-7.

158. Cox ZL, Nelsen CL, Waitman LR, McCoy JA, Peterson JF. Clinical decision support improves initial dosing and monitoring of tobramycin and amikacin. Am J Health Syst Pharm. 2011;68(7):624.

159. Mahoney CD, Berard-Collins CM, Coleman R, Amaral JF, Cotter $\mathrm{CM}$. Effects of an integrated clinical information system on medication safety in a multi-hospital setting. Am J Health Syst Pharm. 2007;64(18).

160. Chen C, Chen K, Hsu C-Y, Chiu W-T, Li Y-CJ. A guideline-based decision support for pharmacological treatment can improve the quality of hyperlipidemia management. Comput Methods Programs Biomed. 2010;97(3):280-5.

161. Kucher N, Koo S, Quiroz R, Cooper JM, Paterno MD, Soukonnikov $\mathrm{B}$, et al. Electronic alerts to prevent venous thromboembolism among hospitalized patients. N Engl j Med. 2005;2005(352):969-77.

162. Roshanov PS, Misra S, Gerstein HC, Garg AX, Sebaldt RJ, Mackay JA, et al. Computerized clinical decision support systems for chronic disease management: A decision-maker-researcher partnership systematic review. Implement Sci : IS. 2011;6:92-.

163. Souza NM, Sebaldt RJ, Mackay JA, Prorok JC, Weise-Kelly L, Navarro T, et al. Computerized clinical decision support systems for primary preventive care: a decision-maker-researcher partnership systematic review of effects on process of care and patient outcomes. Implement Sci. 2011;6:87.

164. Main C, Moxham T, Wyatt JC, Kay J, Anderson R, Stein K. Computerised decision support systems in order communication for diagnostic, screening or monitoring test ordering: systematic reviews of the effects and cost-effectiveness of systems. 2010.

165. Ash JS, Berg M, Coiera E. Some unintended consequences of information technology in health care: the nature of patient care information system-related errors. $\mathrm{J}$ Am Med Inform Assoc. 2004;11(2):104-12.

166. Heselmans A, Van de Velde S, Donceel P, Aertgeerts B, Ramaekers D. Effectiveness of electronic guideline-based implementation systems in ambulatory care settings-a systematic review. Implement Sci. 2009;4(1):82.

167. Varonen H, Kortteisto T, Kaila M. What may help or hinder the implementation of computerized decision support systems (CDSSs): a focus group study with physicians. J Fam Pract. 2008;25(3):162-7.

168. Silhavy P, Silhavy R, Prokopova Z. Patients' Perspective of the Design of Provider-Patients Electronic Communication Services. Int J Environ Res Public Health. 2014;11(6):6231-45.

169. Trivedi MH, Daly EJ, Kern JK, Grannemann BD, Sunderajan P, Claassen CA. Barriers to implementation of a computerized decision support system for depression: an observational report on lessons learned in" real world" clinical settings. BMC Med Inform Decis Mak. 2009;9(1):6.

170. Crosson JC, Isaacson N, Lancaster D, McDonald EA, Schueth AJ, DiCicco-Bloom B, et al. Variation in electronic prescribing implementation among twelve ambulatory practices. J Gen Intern Med. 2008;23(4):364-71.

171. Pizzi LT, Suh D-C, Barone J, Nash DB. Factors related to physicians' adoption of electronic prescribing: results from a national survey. Am J Med Qual. 2005;20(1):22-32.

172. Tan WS, Phang JS, Tan LK. Evaluating user satisfaction with an electronic prescription system in a primary care group. Ann Acad Med Singap. 2009;38(6):494.

173. André B, Ringdal GI, Loge JH, Rannestad T, Kaasa S. The importance of key personnel and active management for successful implementation of computer-based technology in palliative care: results from a qualitative study. Comput Inform Nurs. 2008;26(4):183-9.

174. Wibe T, Edwin E, Husby EH, Vedal T. Implementation of nursing care plan in the Electronic Patient Record (EPR) findings and experiences. Stud Health Technol Inform. 2006;122:309.

175. Berlin A, Sorani M, Sim I. A taxonomic description of computerbased clinical decision support systems. J Biomed Inform. 2006;39(6):656-67.

176. Rousseau N, McColl E, Newton J, Grimshaw J, Eccles M. Practice based, longitudinal, qualitative interview study of computerised evidence based guidelines in primary care. Bmj. 2003;326(7384):314.

177. Lau R, Stevenson F, Ong BN, Dziedzic K, Treweek S, Eldridge S, et al. Achieving change in primary care-causes of the evidence to practice gap: systematic reviews of reviews. Implement Sci. 2016;11(1):40.

178. Abramson EL, Malhotra S, Fischer K, Edwards A, Pfoh ER, Osorio $\mathrm{SN}$, et al. Transitioning between electronic health records: effects on ambulatory prescribing safety. J Gen Intern Med. 2011;26(8):868-74.

179. Devine EB, Williams EC, Martin DP, Sittig DF, Tarczy-Hornoch P, Payne TH, et al. Prescriber and staff perceptions of an electronic prescribing system in primary care: a qualitative assessment. BMC Med Inform Decis Mak. 2010;10(1):72.

180. Grossman JM, Boukus ER, Gross DA, Cohen GR. Physician practices, e-prescribing and accessing information to improve prescribing decisions: Center for Studying Health System Change Washington, DC; 2011.

181. Grossman JM, Gerland A, Reed MC, Fahlman C. Physicians' experiences using commercial e-prescribing systems. Health Aff. 2007;26(3):w393-w404.

182. Amirfar S, Anane S, Buck M, Cohen R, DiLonardo S, Maa P, et al. Study of electronic prescribing rates and barriers identified among providers using electronic health records in New York City. J Innov Health Inform. 2011;19(2):91-7.

183. Lapane KL, Rosen RK, Dubé C. Perceptions of e-prescribing efficiencies and inefficiencies in ambulatory care. Int $\mathrm{J}$ Med Inform. 2011;80(1):39-46.

184. Davis FD. Perceived usefulness, perceived ease of use, and user acceptance of information technology. MIS Q. 1989:319-40.

185. Martinez MA, Kind T, Pezo E, Pomerantz KL. An Evaluation of community health center adoption of online health information. Health Promot Pract. 2008;9(1):59-67.

186. Paré G, Sicotte C, Jacques H. The effects of creating psychological ownership on physicians' acceptance of clinical information systems. J Am Med Inform Assoc. 2006;13(2):197-205.

187. Yusof MM, Stergioulas L, Zugic J. Health information systems adoption: findings from a systematic review. Stud Health Technol Inform. 2007;129(1):262.

188. Marcy TW, Skelly J, Shiffman RN, Flynn BS. Facilitating adherence to the tobacco use treatment guideline with computer-mediated decision support systems: physician and clinic office manager perspectives. Int J Prev Med. 2005;41(2):479-87.

189. Gravel K, Légaré F, Graham ID. Barriers and facilitators to implementing shared decision-making in clinical practice: a systematic review of health professionals' perceptions. Implement Sci. 2006;1(1):16.

190. Ammenwerth E, Iller C, Mahler C. IT-adoption and the interaction of task, technology and individuals: a fit framework and a case study. BMC Med Inform Decis Mak. 2006;6(1):3.

191. Reisman Y. Computer-based clinical decision aids. A review of methods and assessment of systems. MED INF. 1996;21(3):179-97.

192. Yarbrough AK, Smith TB. Technology acceptance among physicians: a new take on TAM. Med Care Res Rev. 2007;64(6):65072 . 